Review

\title{
Recent Advances in the Use of Iron-Gold Hybrid Nanoparticles for Biomedical Applications
}

\author{
Mariam Abdulaziz M. Tarkistani, Varsha Komalla and Veysel Kayser *(D) \\ Sydney Pharmacy School, Faculty of Medicine and Health, The University of Sydney, \\ Camperdown, NSW 2006, Australia; mtar8733@uni.sydney.edu.au (M.A.M.T.); \\ varsha.komalla@sydney.edu.au (V.K.) \\ * Correspondence: veysel.kayser@sydney.edu.au; Tel.: +61-2-9351-3391
}

Citation: Tarkistani, M.A.M.;

Komalla, V.; Kayser, V. Recent

Advances in the Use of Iron-Gold Hybrid Nanoparticles for Biomedical Applications. Nanomaterials 2021, 11, 1227. https://doi.org/10.3390/ nano11051227

Academic Editor: Magdalena Oćwieja

Received: 8 April 2021

Accepted: 28 April 2021

Published: 6 May 2021

Publisher's Note: MDPI stays neutral with regard to jurisdictional claims in published maps and institutional affiliations.

Copyright: (c) 2021 by the authors. Licensee MDPI, Basel, Switzerland. This article is an open access article distributed under the terms and conditions of the Creative Commons Attribution (CC BY) license (https:// creativecommons.org/licenses/by/ $4.0 /)$.
Abstract: Recently, there has been an increased interest in iron-gold-based hybrid nanostructures, due to their combined outstanding optical and magnetic properties resulting from the usage of two separate metals. The synthesis of these nanoparticles involves thermal decomposition and modification of their surfaces using a variety of different methods, which are discussed in this review. In addition, different forms such as core-shell, dumbbell, flower, octahedral, star, rod, and Janusshaped hybrids are discussed, and their unique properties are highlighted. Studies on combining optical response in the near-infrared window and magnetic properties of iron-gold-based hybrid nanoparticles as multifunctional nanoprobes for drug delivery, magnetic-photothermal heating as well as contrast agents during magnetic and optical imaging and magnetically-assisted optical biosensing to detect traces of targeted analytes inside the body has been reviewed.

Keywords: nanomaterials; nanohybrids; magnetic plasmonic nanoparticles; gold nanoparticles; iron oxide nanoparticles; surface functionalization; biomedical applications

\section{Introduction}

Nanoparticles (NPs) usually possess distinct chemical and physical properties compared to macromolecules, mainly due to their smaller sizes. These properties include conductance, magnetism, chemical interactions, and optical properties [1] as well as surface area, shape, magnetism, and permeability, affecting their characteristics and making them unique in their functioning [2].

NPs are ubiquitously present around us in nature, for instance, in our food, e.g., casein micelles [3]; in the biological matter such as viruses [4]; and other environmental sources such as ash, sand, and dust [5]. Due to their smaller sizes, NPs can pass through the biological membranes and interact actively with cell organelles and cellular structures such as proteins, DNA, and RNA [1], and hence, they can be used as delivery vehicles for drugs to improve their circulation time and bioavailability [6].

Cancer is one of the major causes of death worldwide. Patients, when treated with traditional chemotherapy, suffer from various side effects, as small molecule drugs are non-selective and affect normal cells or tissues along with cancerous cells [7]. Within cancerous cells, the small size of NPs can enhance the concentration of the drugs inside the tumor by preferential accumulation due to the large pore size of neo-vasculatures and defective lymphatic system, which is defined as an enhanced penetration and retention effect [8].

Different types of NPs that are frequently used in medicine include metallic nanoparticles, dendrimers, liposomes, carbon nanotubes, and nanocrystals [9]. Among these, magnetic iron oxide NPs, particularly maghemite $\left(\gamma-\mathrm{Fe}_{2} \mathrm{O}_{3}\right)$ and magnetite $\left(\mathrm{Fe}_{3} \mathrm{O}_{4}\right)$ with a size of less than $20 \mathrm{~nm}$, exhibit superparamagnetic behavior. These structural properties make the NPs ideal for several biomedical applications, including magnetic resonance 
imaging (MRI) [10], magnetically guided drug delivery [11], magnetic hyperthermia [12], and biosensors [13].

On the other hand, gold NPs are the most widely used and studied due to their easy preparation, high stability, well-established surface functionalization chemistry, and unique optical properties. Furthermore, gold NPs exhibit localized surface plasmon resonance providing efficient absorption and scattering of light at specific wavelengths. These wavelengths can be tuned according to their shapes and sizes. This property makes gold NPs an ideal choice as calorimetric sensors and nanoprobes for surface-enhanced Raman spectroscopy (SERS) and labels for imaging or photothermal agents for cancer therapy. Gold NPs can be easily functionalized using thiols and amines, while iron-oxide NPs can be functionalized using catechols, silanes, diol carboxylic groups, or amines [14,15].

In the last few years, new composite nanostructures have attracted considerable attention, particularly those based on bimodal metals, such as gold $(\mathrm{Au})$ and iron $\left(\mathrm{Fe}_{3} \mathrm{O}_{4}\right)$. More specifically, since Au possesses excellent properties as mentioned earlier, the construction of $\mathrm{Au}$-iron oxide-based nanostructures would be extremely valuable providing complementary modalities for accurate imaging or diagnosis or offer an additional therapeutic avenue for enhanced cancer treatment, thus overcoming the limitation of individual treatment approaches [16]. Moreover, these nanohybrids effectively incorporate enhanced properties such as magnetic response, light absorption, and thermal effect in one nanoplatform [17]. $\mathrm{Au}$ NP catalysts were used in applications such as carbon monoxide oxidation, the reduction of aromatic nitro compounds etc. Although small volumes of Au NPs are required for catalysis, large amounts are still needed to carry out processes at industrial scale, which is uneconomical. One way to achieve low-cost gold-based catalysts is to create a gold hybrid. Larson and co-workers demonstrated superior catalytic properties for iron-gold NPs when compared to gold nanoparticles themselves [18].

Iron-gold-based NPs facilitate the attachment of different functional groups, allowing the conjugation of different drugs and can possess multiple functionalities in one single nanostructure coming from two different domains $[19,20]$. Indeed, the combination of plasmonic and magnetic properties is extremely appealing for biomedical applications, including hyperthermia [16], protein biomarkers detection [21], targeted delivery of DNA, siRNA [22] drug solubility improvement [7], tumor imaging, gene expression product detection, and targeted drug delivery [23]. These encouraging features together with the ease of surface modification make iron oxide-gold nanohybrids a robust platform for manifold biomedical applications.

Some excellent reviews have been published on the use of iron oxide-gold-based NPs in the field of nanomedicine [24]. However, we have reviewed important findings focusing on advances of iron oxide-gold-based structures in recent years. Herein, we discuss the general properties of nanoparticles, iron oxide, and its surface functionalization with inorganic and organic compounds, synthesis, and structures of hybrid iron-gold NPs, as well as a brief insight into biomedical applications of iron-gold NPs and their toxicity.

\section{Properties of Nanoparticles}

The novel properties and versatile features of NPs make them a preferred choice for a variety of applications in different fields, such as nanofabrication, surface engineering, and tribology [25]. These unique features of NPs are attributed to their notable sizedependent characteristics which are directly linked to their increased surface area. The size-to-surface ratios of NPs changes the atomic density of particles and give them their distinct physiochemical or mechanical characteristics from the bulk material. NPs with superior mechanical properties relative to the micro or bulk particles improve the strength and quality of processes such as microfabrication, which affect the tribological features of lubricants [26] and strengthen composite coatings [27]. An in-depth knowledge about their mechanical and physicochemical properties, such as elastic modulus or hardness, surface charge, adhesion or friction, colloidal stability, effects of size, and ligand chemistry, is usually needed for many practical applications. 


\subsection{Hardness or Elastic Modulus of Nanoparticles}

Hardness and elastic modulus are among the basic mechanical properties of NPs, and generally, a detailed characterization should be performed. The elastic modulus of NPs can be measured by compressing or bending the NPs by AFM, and in the case of spherical polymer nanoparticles, a uniform size-dependent, mechanical property is not observed thus far. Ramos et al. have reported that the elastic modulus and hardness of six-fold symmetry gold nanoparticles are greater than those of the bulk phase due to the production of stacked faults and dislocation in crystallographic direction [28].

\subsection{Adhesion or Frictional Effects in Nanoparticles}

The adhesive and frictional forces in NPs play a key role in determining their colloidal stability, lubrication, nanofabrication, nanodevice design, and drug delivery. Interactions of NPs with polished surfaces, in addition to good control on their mechanical properties, are crucial for improving the surface quality and enhancing material removal [29]. The adhesion of gold NPs (AuNPs), which are prepared on silicon substrates with a diameter of $25 \mathrm{~nm}$, has been reported to decrease in the presence of hydrophobic interfaces [30]. In another study on spherical AuNPs, Maharaj et al. have reported that friction and wear of AuNPs decrease when water is added. AFM can be employed to observe interactive forces among NPs, the AFM tip probe, and the substrate, including the Van der Waals (VDW), electrostatic, capillary, frictional, and repulsive contact forces [31]. Moreover, several types of motions such as sliding, rotation, and rolling were also observed to be important when dealing with friction at nanoscale [32].

\subsection{Effect of Size}

The NP size crucially affects the type of particle location inside the body [33,34]. For instance, in a study by Carlos et al., $10 \mathrm{~nm}$ and $30 \mathrm{~nm}$ gold NPs accumulated more in liver and kidney as compared to $60 \mathrm{~nm}$ ones, which have been found more in spleen postinjection in Wistar rats [35]. If the size of NPs is large, it poses a physical difficulty to cross the lipid membrane of the cell. The size of NPs as well as the density of the receptor are key parameters in determining the particle uptake through receptor-mediated endocytosis [36].

\subsection{Effect of Surface Charge or $p K a$}

The increase in the surface charge or ionization leads to the increase in the uptake driving force of NPs, thereby permitting them to translocate the cell membrane easier. It serves as opposition to the influence of increased size. The size of the NP can be easily manipulated when compared to increasing the surface charge or ionization $[37,38]$.

\subsection{Effect of Ligand Chemistry}

Ligand chemistry is another important factor when considering the translocation of NPs through the membrane. By changing the hydrophobic nature of NPs to a hydrophilic nature, the passage of NPs through the membrane is enhanced rather than the NPs being embedded inside it or attached to the surface [37]. The processing of AuNPs with hydrophobic ligands has been proposed to enhance targeted delivery and facilitate various diagnostic and therapeutic applications [39]. Overall, the enhancement of the hydrophobic nature of NPs aids in trapping the NPs inside the membrane due to the enhancement in the enthalpic reactions between the membrane and ligand. When NPs are placed inside the lipid membrane, those comprising high hydrophobic ligands exhibit high free energy gains compared to NPs comprising less hydrophobic ligands, helping NPs to be entrapped inside membranes [37,38].

\subsection{Plasmonic Nanoparticles}

Interactions of metallic NPs with light acquire a collection of free electrons called plasmons, further producing the surface plasmon resonance (SPR). The localized SPR phenomena generated by noble metal NPs such as gold are popular due to their resonance 
frequencies falling in both visible and near-infrared regions [40,41]. The LSPR phenomenon is studied and exploited for biomedical applications such as photo-induced hyperthermia and photo-induced bioimaging [14,41,42].

The size, morphology, and composition of noble metal NPs needs to be precisely controlled, keeping in mind the permittivity of the surrounding medium to develop a robust application-oriented LSPR peak suitable for biomedical applications [40].

Properties of plasmonic NPs such as optical scattering as well as mechanical and photothermal features depend on their surface properties, heat capacity, optical pulse length, and clusterization state [43].

\subsection{Magnetic Nanoparticles}

By exploiting the high magnetization property with a functionally designed surface, $\mathrm{Fe}_{3} \mathrm{O}_{4}$ NPs can be successfully attached to the target cell or tissue, in a selective manner; hence, magnetic NPs can be used in different medical fields from diagnosis to treatment. To this end, the particle surface can be functionalized so that NPs appropriately target a ligand and also carry a drug load to the desired target via external or internal stimuli [44]. Various strategies have been adopted for surface functionalization with the use of different coating agents and various biomolecules that ensure the ability of magnetic NPs to reach the desired target. A summary of critical properties of iron-gold NPs and their implications is compiled in Table 1.

Table 1. A comprehensive list of properties and implications of nanoparticles.

\begin{tabular}{|c|c|c|}
\hline Properties & Implication & References \\
\hline Hardness or elastic module & $\begin{array}{l}\text { Helps to better accomplish versatile goals and } \\
\text { control action mechanisms. }\end{array}$ & [45] \\
\hline $\begin{array}{l}\text { Adhesion or } \\
\text { frictional effects }\end{array}$ & $\begin{array}{c}\text { Determines the colloidal stability, lubrication, } \\
\text { nanofabrication, nanodevice design and drug } \\
\text { delivery capabilities. }\end{array}$ & [29] \\
\hline Nanoparticle size & $\begin{array}{l}\text { Increasing the size enhances the physical } \\
\text { difficulty to cross the lipid membrane of the cell } \\
\text { and adversely affects the particle uptake through } \\
\text { receptor-mediated endocytosis. }\end{array}$ & [36] \\
\hline Surface charge or $\mathrm{pKa}$ & $\begin{array}{l}\text { Increasing the surface charge/ionization } \\
\text { increases the driving force of NPs and makes } \\
\text { them translocate the cell membrane. It serves as } \\
\text { opposition to the influence of enhanced size. }\end{array}$ & {$[37,38]$} \\
\hline Ligand chemistry & $\begin{array}{l}\text { AuNPs processing with hydrophobic ligands } \\
\text { enhances targeted delivery and facilitates } \\
\text { various diagnostic and therapeutic applications. } \\
\text { The hydrophobic nature of the particle helps in } \\
\text { trapping it inside the membrane by enhancing } \\
\text { enthalpic reactions between the membrane and } \\
\text { the ligand. NPs with high hydrophobic ligands } \\
\text { possess high free energy gains as compared to } \\
\text { the NPs with less hydrophobic ligands when } \\
\text { placed inside lipid membranes and would help } \\
\text { entrap the NPs inside the membrane. }\end{array}$ & {$[37,38]$} \\
\hline Plasmonic & $\begin{array}{l}\text { Plasmonic properties of noble metallic NPs are } \\
\text { exploited for biomedical applications such as } \\
\text { hyperthermia and bioimaging. }\end{array}$ & {$[14,41,42,46]$} \\
\hline Magnetic & $\begin{array}{c}\text { High magnetic properties with functionally } \\
\text { designed surface of iron oxide NPs can be } \\
\text { exploited in hyperthermia and } \\
\text { image-guided delivery. }\end{array}$ & {$[12,16]$} \\
\hline
\end{tabular}




\section{Iron Oxide Nanoparticle Functionalization}

For numerous biomedical applications, it is necessary to modify the NPs' surface with a suitable shell. Modification is crucial due to the following reasons:

1. Due to their nanometer size, surface modification is required in order to reduce the surface energy.

2. Ligands bind inefficiently, and drug delivery fails if the surface of $\mathrm{Fe}_{3} \mathrm{O}_{4} \mathrm{NPs}$ is not functionalized.

3. Uncoated $\mathrm{Fe}_{3} \mathrm{O}_{4} \mathrm{NPs}$ can form free radicals.

4. To use $\mathrm{Fe}_{3} \mathrm{O}_{4}$ for biological applications that are inside the cells and proteins, it is appropriate to bind them with a suitable ligand for selective targeting [47].

When the surface of $\mathrm{Fe}_{3} \mathrm{O}_{4}$ NPs is modified using organic or inorganic materials, nontoxic and biocompatible NPs are formed, which can be used for biomedical applications [48,49]. Inorganic materials such as gold and silica can be used to coat $\mathrm{Fe}_{3} \mathrm{O}_{4} \mathrm{NPs}$. These inorganic materials enhance the binding ability of the NPs to biomolecules and render increased stability to the iron-gold NPs surface. In addition, when $\mathrm{Fe}_{3} \mathrm{O}_{4} \mathrm{NPs}$ are coated with organic materials, the agglomeration of these $\mathrm{Fe}_{3} \mathrm{O}_{4} \mathrm{NPs}$ in the solution is prevented [47]. Figure 1 provides the schematic representation of the commonly used molecules to functionalize the iron nanoparticles.

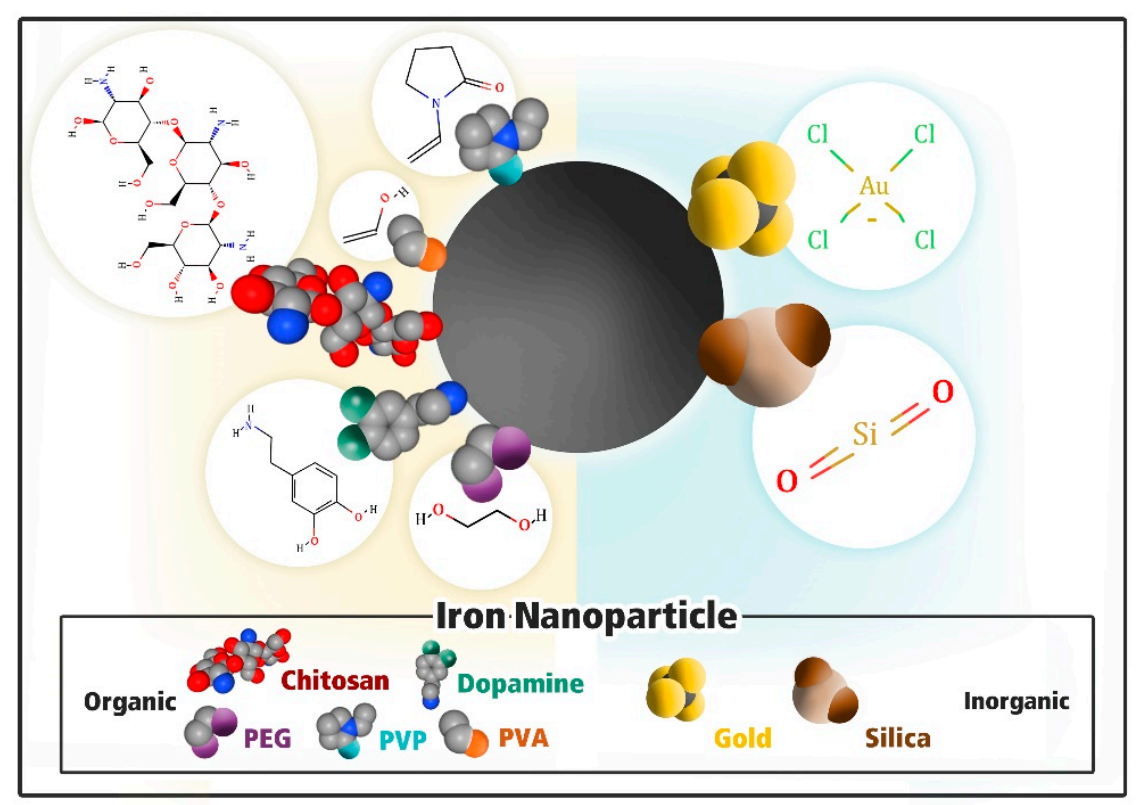

Figure 1. An iron oxide nanoparticle with different hydrophilic ligand molecules. The schematic representation of a surface modification of iron oxide nanoparticles. Left to right: organic to inorganic polyethylene glycol (PEG), polydopamine (PDA), chitosan, polyvinyl alcohol (PVA), polyvinyl pyrrolidone (PVP), gold, and silica. Molecule structures were taken from the pubchem.ncbi.nlm.gov and displayed as surfaces and modeled from their chemical structure with a space-filling model.

\subsection{Modification with Inorganic Material}

\subsubsection{Gold $(\mathrm{Au})$}

Gold enhances the functionality and stability of magnetic NPs in aqueous solutions. In addition, it exhibits optical properties due to Au's surface plasmonic resonance (SPR) [50]. The process involves the reduction of an $\mathrm{Au}$ precursor in the presence of $\mathrm{Fe}_{3} \mathrm{O}_{4}$ nanoparticles. Iron-gold NPs can be synthesized by the reduction of $\mathrm{HAuCl}_{4}$. However, this $\mathrm{Au}$ coating process is difficult to do at room temperature due to the incompatibility of the underlying chemistry [51]. Alternatively, an iron-gold shell can be constructed at $180-190{ }^{\circ} \mathrm{C}$ using 1,2-hexadecanediol as a reducing agent. At high temperatures, surfactants are ad- 
sorbed on the iron-gold NPs' surface [52]. Generally, TEM is employed to determine the thickness of nanoparticles [53].

\subsubsection{Silica $\left(\mathrm{SiO}_{2}\right)$}

In a colloid system, $\mathrm{SiO}_{2}$ is used as an inorganic coating for the NPs surface. A silica shell over the NP surface renders protection against toxicity, enhances chemical stability, and prevents the aggregation of iron-gold NPs in the liquid phase [54]. Stabilization induced by silica coatings on the surface of $\mathrm{Fe}_{3} \mathrm{O}_{4}$ NPs occurs in two different ways: the first one is by protecting the dipole interaction with the shell of silica. Secondly, by enhancing the Coulomb repulsion of $\mathrm{Fe}_{3} \mathrm{O}_{4}$ by silica [55].

\subsection{Modification with Organic Materials}

\subsubsection{Polydopamine}

Dopamine is a biomaterial derived from dihydroxy-L-phenylalanine (DOPA), and it belongs to the class of catecholamines, which plays a significant role in achieving adhesions to muscles. It can interact with multiple substrates via covalent and non-covalent bonds [56]. Polydopamine (PDA) is a versatile polymerization product of dopamine monomers that can attach to metallic surfaces [56]. An organic solvent is not required in the synthesis of PDA due to its strong adhesive properties. Diverse particle sizes can be achieved by the surface modification of PDA by varying the reaction conditions, including the dopamine concentration, $\mathrm{pH}$, reaction time, temperature, and oxidants [57]. PDA modifications enhance the drug-loading ability of the NPs, making them effective drug carriers [56].

\subsubsection{Poly Vinyl Pyrrolidone (PVP)}

Poly vinyl pyrrolidone is a water-soluble polymer, and because of its distinct properties such as high chemical and thermal resistance, unique wetting, binding, and filmforming properties, it is widely used in various biomedical applications [58]. It exhibits a neutral charge, as well as biocompatibility and good aqueous solubility. A PVP coating is strengthened by covalent bonds, and it is known to enhance the stability of superparamagnetic iron oxide NPs (SPIONS) [59]. PVP-coated iron NPs can be efficiently used as MRI contrast agents $[60,61]$.

\subsubsection{Chitosan}

Chitosan is a biopolymer with diverse physical and chemical properties including but not limited to possessing high charge density at $\mathrm{pH}<6.5$, amenability for chemical modification, and bacteriostatic in nature [62], rendering it with novel characteristics and functions; thus, it can be extensively used in biomedical applications. This biopolymer is environmentally friendly, biocompatible, non-antigenic and nontoxic [63]. Therefore, it is beneficial to encapsulate $\mathrm{Fe}_{3} \mathrm{O}_{4}$ nanoparticles within chitosan. The amino and hydroxyl groups on chitosan form complexes with the $\mathrm{Fe}_{3} \mathrm{O}_{4}$ surface, providing stability and biocompatibility. For therapeutic drug delivery and MRI, the positive charge of its amino group interacts with the negative charge of the nucleic acid, making it biocompatible [64].

\subsubsection{Polyethylene Glycol (PEG)}

Polyethylene glycol is a biocompatible biopolymer. A study by Nathan et al. demonstrated that PEG enhances the dispersion of iron oxide NPs and the stability of NP solution [65]. In addition, PEG can be linked to different biomolecules by serving as a spacer [66]. PEGylated superparamagnetic iron oxide NPs (SPIONS) demonstrated highest relaxation times, a requirement for better MRI imaging, and were resistant against aggregation [67].

\subsubsection{Polyvinyl Alcohol (PVA)}

PVA is a biopolymer with widespread applications in biomedicine. When an irongold NPs' surface is coated with PVA, PVA reduces agglomeration, and the NPs show good 
monodispersity [68]. PVA provides high biocompatibility, resistance to protein adsorption, and cell adhesion [69]. Therefore, for the coating of SPIONs, PVA is a good biocompatible material with excellent water solubility.

\section{Iron-Gold Bifunctional Nanoparticles}

Owing to advances in synthetic methodologies, bifunctional iron-gold NPs with various shapes, sizes, chemical, and physical properties are being extensively tested in biomedical applications including targeted drug delivery [23], biosensing [70], photothermal therapy [71], and different immunoassays [72]. Compared to other NPs, bifunctional iron-gold nanoparticles exhibit significant benefits due to their small size, large surface-tovolume ratio, optical characteristics, and high magnetic properties [73]. The use of these NPs in the aforementioned applications depends on their properties, i.e., slow oxidation, increased magnetic susceptibility, low toxicity, and high saturation magnetization.

\subsection{Structure of Iron-Gold Nanohybrids}

Depending on their use, iron-gold NPs can be designed in various structures. The appropriate particle structure can be obtained by different factors, including particle shape, size, and chemical composition. The most desired morphologies of the iron-gold NPs include core-shell, dumbbell-shaped, Janus-shaped, flower-shaped, star-shaped, octahedralshaped, and rod-shaped, as depicted in Figure 2. The synthesis of these morphologies, shape, and final performance depends on their junctional mode and interfacial morphology of the heterodimer structures [74].

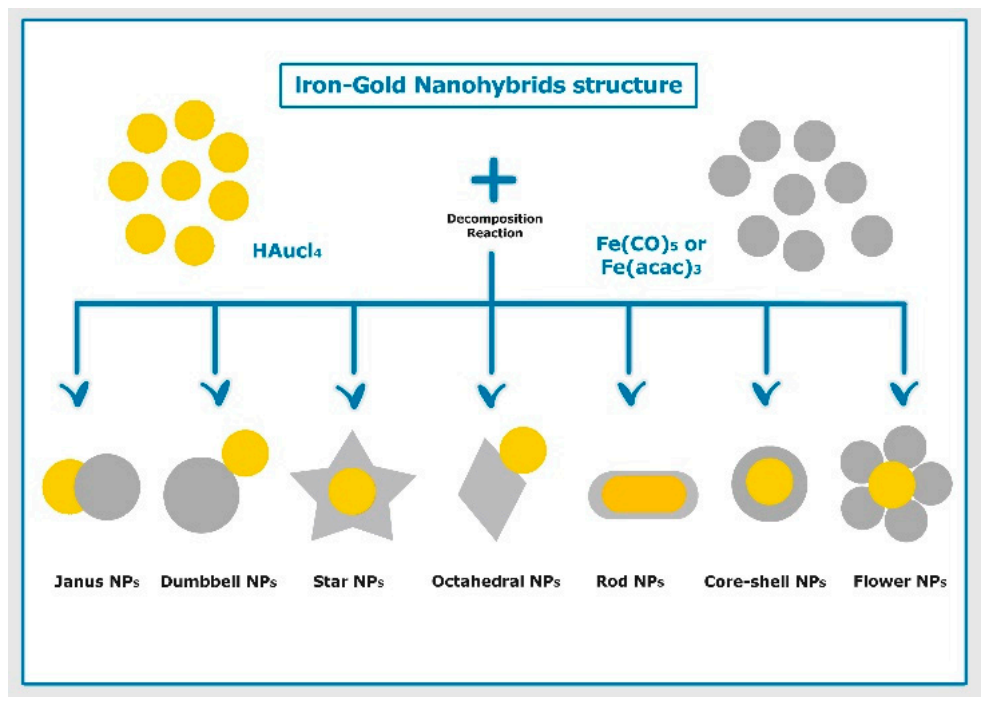

Figure 2. Schematic illustration of different structures of iron-gold hybrid nanoparticles prepared using thermal decomposition method.

Randomly decorated NPs are formed by the random joining of components during the seed-mediated synthesis of the heterodimers. Large building blocks are the hosts of the guest particles, and the used components can form different shapes, including irregular nongeometric, spherical, or irregular [75]. Different morphologies result in differences in the biocompatibility and magnetic properties of the NPs and lead to increased biocompatibility, magnetization, and specific absorption rates [76].

\subsubsection{Core-Shell Shape}

A core-shell structure is composed of an inner core coated with one or more layers (shells) of different materials. The core-shell structure has an advantage over other morphologies due to its high stability and tenability [77] and possesses a small size and large surface area [78]. 
Core-shell nano-heterostructures based on iron and gold can be prepared via a seedassisted method by the incorporation of a reducing agent and slowing down the heating process [79].

Iron-gold core hollow shell nanoparticles demonstrate potential for use as MRI agents [80]. The selection of core and shell depends on the kind of application. For instance, for drug delivery purposes, the core can be iron and the shell can be silica/polymer; whereas for separable catalysis, the shell would be a metal nanocluster [81]. For designing a cancer nanotherapeutic that can perform chemotherapy/photothermal effect and multimodal cancer imaging, the magnetic core can be used for imaging, and a secondary coating layer with a porous silica layer can be used for encapsulating a chemotherapeutic agent. Lastly, a second shell coating with gold nanorods can give photothermal effects. Furthermore, the core-shell structure can retain the size, structure, and catalytic activity of gold NPs under thermal and mechanical stress when covered by metal oxides [82].

The incompatible surface energies of gold and iron make it difficult to construct core-shell structures. During preparation, parts of the iron oxide core are often exposed due to incomplete coating, which further causes heterogenous biofunctionalization and dysfunctional optical applications. One strategy to overcome this problem is to include an intermediate layer between iron and gold in the core-shell structure [83].

\subsubsection{Dumbbell Shape}

Dumbbell-shaped nanoparticles were reported first in 2005 [84]. In this morphology, local changes in the electronic structure occurs along the point of attachment between iron and gold, resulting in the alterations in the magnetic, optical, and catalytic properties of NPs [85]. A TEM micrograph of dumbbell-shaped iron-gold NPs has been recorded as part of a study by our group, as seen in Figure 3a (Kayser et al. unpublished). Dumbbellshaped $\mathrm{Au}-\mathrm{Fe}_{3} \mathrm{O}_{4}$ systems have numerous advantages: (1) They can be made directly without any pretreatment [84]. (2) They have both optically active plasmonic ( $\mathrm{Au})$ unit and magnetic $\left(\mathrm{Fe}_{3} \mathrm{O}_{4}\right)$ properties, which makes them ideal for both magnetic and optical detection. (3) The presence of both particles on the surface makes it favorable for targetspecific delivery and imaging functions. (4) They support drug release and cell targeting, as the small particle size provides an advantage to accommodate therapeutic molecules, proteins, antibodies, and a few strands of DNA [86]. Studies on the dumbbell heterodimers have demonstrated that the symmetry and free surface areas of dumbbell heterodimers are greater than those of randomly decorated ones, making them desirable for use in photoand bio-catalysis applications [87]. The synthesis of the iron-gold heterodimers by the seed-mediated technique of non-spherical magnetic particles can affect their plasmonic properties during the interfacial morphology [74].

a)

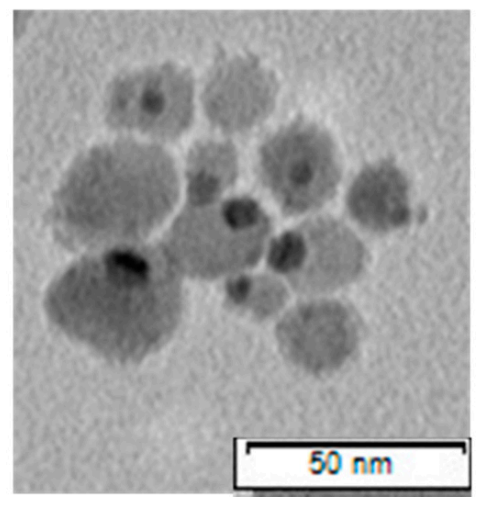

b)

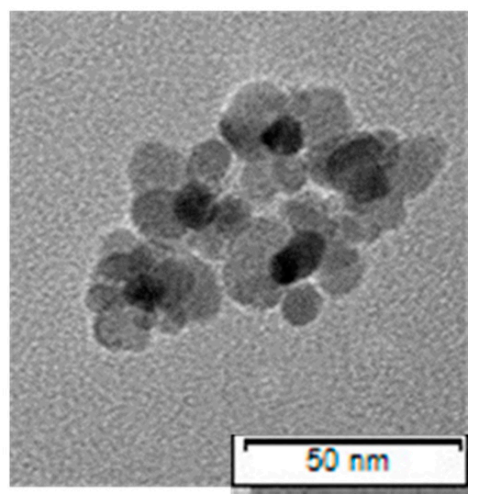

Figure 3. Representative TEM micrographs illustrating iron-gold nanostructures: (a) nanodumbbells, (b) nanoflowers taken from Kayser et al. (unpublished). 


\subsubsection{Janus Shape}

Janus-shaped NPs are heteroparticles with two chemically different domains. These NPs exhibit unique structures with different surface characteristics and similar shapes and dimensions. Their morphology and composition render multimodal and versatile capabilities for use as drug delivery carriers and contrast agents in future medicine [88]. Owing to their resemblance to natural biomolecules, Janus-shaped NPs are suitable for use in biomedical applications, and they exhibit improved biocompatibility as well as magnetic and plasmonic properties [89]. Moreover, Janus NPs can accommodate drugs with different solubilities without influencing each other in their two distinct domains and release drugs independently by different stimuli. For instance, in a study by Zhang et al., poly(3-caprolactone)-gold nanocage/ferric hydroxide-poly (acrylic acid) Janus-shaped NPs were developed and loaded with two anticancer drugs, i.e., a hydrophilic doxorubicin and a hydrophobic docetaxel in two domains. These Janus NPs demonstrated independent control release of docetaxel and doxorubicin as a function of $\mathrm{pH}$ and NIR, respectively [90].

Furthermore, the unique anisotropic surface properties of Janus-shaped NPs allow them to house different functionalities in one nanoplatform. For example, in a study by Qi Zhang et al., the Au component of Janus NPs were functionalized with folic acid and poly (ethylene glycol) to obtain cancer targeting and high contrast for X-ray computed tomography. Concurrently, the $\mathrm{Fe}_{3} \mathrm{O}_{4}$ component acted as a delivery vehicle for doxorubicin, a magnetic resonance imaging contrast agent and a photothermal therapy agent [91]. Hence, both the components in Janus NPs can be functionalized and together provide an excellent nanoplatform with multiple functionalities due to these unique properties.

\subsubsection{Flower-Shape}

Flower-shaped NPs are comprised of three to five petals of iron oxide and a core $\mathrm{Au}$, as seen in Figure 3b (Kayser et al. unpublished). There are only few studies so far on flowershaped iron-gold NPs [20,92]. These flower-shaped nanoparticles have been successfully used as efficient matrices for laser desorption and ionization mass spectrometry (LDI-MS). They can be utilized to target cancer cells and capture ATP molecules in the detection and analysis of metabolites from cancer cells and molecular imaging [20,92].

\subsubsection{Star Shape}

Star-shaped heterodimers are synthesized from the Janus particles and exhibit slight morphological changes. Moreover, these NPs exhibit improved plasmonic and magnetic properties in comparison with those of randomly decorated and spherical structures [14]. As such, these NPs can be effectively used as contrast agents for different imaging techniques, such as X-ray computed tomography, MRI, optical microscopy, and photoacoustic imaging [14].

Furthermore, the spiky morphology of the Au imparts an enhanced electric field to the NP due to focalization of the plasmonic electromagnetic field at the sharp tips and edges. This local amplification effect allows highly sensitive magnetic detection of target molecules representing an interesting application for SERS detection using $\mathrm{Fe}_{3} \mathrm{O}_{4} @ \mathrm{Au}$ nanostars [93]. Nguyen and co-workers reported the magnetically-assisted surface-enhanced Raman spectroscopy (SERS) performance of Fe3O4@Au nanostars for detection of traces of thiram, a popular pesticide, in water. $\mathrm{Fe} 3 \mathrm{O} 4 @ \mathrm{Au}$ nanostars were able to detect thiram at solute concentrations as low as $10^{-8} \mathrm{M}$ [94].

\subsubsection{Octahedral Shape}

Octahedral-shaped NPs have bulk magnetic properties, and because of their shape and high magnetization, they have superior in vitro and in vivo T2 relaxivity and can be used as contrast agents in MRI. These NPs are comprised of 20-30 nm magnetite octahedral nanocrystals, and they are grown on Au NPs by modified-wet chemical synthesis. These NPs exhibit two functional surfaces that are suitable for theranostic applications, including as the delivery of drugs in cancer treatment and dyes in intravital microscopy [95]. 
Octahedral NPs have demonstrated superior characteristics such as high relaxometric efficiency compared to commercial $\mathrm{T}_{2}$ contrast agents and excellent heat dissipating capacity in vitro [96].

\subsubsection{Rod Shape}

The polymer-coated gold nanorods upon mixing with iron salts and base resulted in iron-coated gold nanorods. These nanorods exhibited milder response under the application of an externally applied magnetic field (AMF) [97]. This is because magnetic manipulation is a lengthy process, and moreover, due to the thinness of the magnetic coating compared to the high mass of the core gold, these iron oxide-coated gold nanorods demonstrated poor response to AMF. However, nanorods formed by electrostatic interactions of pre-existent iron NPs and gold nanorods were more responsive to AMF. Nevertheless, they demonstrated problems in the reproducibility and uniformity of iron oxide coating [97]. In another study by Brian et al., premade iron NPs were stabilized by hydrophobic ligands and allowed to aggregate with silicon-coated gold nanorods present in non-polar solvent. The iron-gold nanorods prepared by this method were highly responsive to AMF. When compared to other methods, the heteroaggregation approach is simple and efficient for preparing iron oxide-gold nanorods due to the adjustable polarity of the solvents [98].

A comprehensive list of the different structures and properties of iron-gold NPs is summarized in Table 2.

Table 2. Different structures of gold iron oxide nanoparticles, their properties and implications.

\begin{tabular}{|c|c|c|c|c|c|}
\hline Structure & SIZE (nm) & Properties & Application & Implication & References \\
\hline Flower & $30-300 \mathrm{~nm}$ & $\begin{array}{l}\text { Comprises three to } \\
\text { five petals of iron } \\
\text { oxide and a core } \mathrm{Au}\end{array}$ & $\begin{array}{l}\text { Targeted cancer, } \\
\text { LDI-MS }\end{array}$ & $\begin{array}{l}\text { Suitable for use as efficient matrices } \\
\text { in LDI-MS. Use in biomedical } \\
\text { applications, such as targeting cancer } \\
\text { cells and capture of ATP molecules. } \\
\text { Use in detection and analysis of } \\
\text { metabolites from cancer cells and } \\
\text { molecular imaging. }\end{array}$ & [20] \\
\hline Star & $\approx 70-150 \mathrm{~nm}$ & $\begin{array}{l}\text { Improved plasmonic } \\
\text { and magnetic } \\
\text { properties }\end{array}$ & X-ray, MRI & $\begin{array}{l}\text { Suitable as contrast agents for } \\
\text { different imaging techniques, such as } \\
\text { X-ray computed tomography, MRI, } \\
\text { optical microscopy, SERS detection of } \\
\text { target molecules, and } \\
\text { photoacoustic imaging. }\end{array}$ & {$[14,93,94]$} \\
\hline Dumbbell & $\approx 10-60 \mathrm{~nm}$ & $\begin{array}{l}\text { Optically active } \\
\text { plasmonic and high } \\
\text { magnetic properties }\end{array}$ & $\begin{array}{l}\text { Photothermal, } \\
\text { biocatalysis }\end{array}$ & $\begin{array}{l}\text { High symmetry and large free surface } \\
\text { areas make them desirable for use in } \\
\text { the photo- and } \\
\text { biocatalysis applications. }\end{array}$ & [87] \\
\hline $\begin{array}{l}\text { Core- } \\
\text { shell }\end{array}$ & 70 to $250 \mathrm{~nm}$ & $\begin{array}{l}\text { High stability and } \\
\text { tenability }\end{array}$ & $\begin{array}{l}\text { Catalysis and } \\
\text { cancer therapy }\end{array}$ & $\begin{array}{l}\text { Colloidal stability in dispersion } \\
\text { ensures a better shelf life. }\end{array}$ & [99] \\
\hline Octahedral & $25 \mathrm{~nm}$ & $\begin{array}{l}\text { High magnetization } \\
\text { High crystallinity, } \\
\text { relaxometric efficiency }\end{array}$ & MRI & $\begin{array}{l}\text { Superior in vitro and in vivo T2 } \\
\text { relaxivity, suitable for use as contrast } \\
\text { agents in MRI. Two functional } \\
\text { surfaces make them suitable for } \\
\text { theranostic applications. }\end{array}$ & {$[95,96]$} \\
\hline Rod & $8 \mathrm{~nm}$ & $\begin{array}{l}\text { Enhanced plasmonic } \\
\text { properties }\end{array}$ & $\begin{array}{l}\text { Photothermal } \\
\text { therapy }\end{array}$ & $\begin{array}{l}\text { Robust iron oxide-gold nanorods can } \\
\text { be prepared using the } \\
\text { heteroaggregation approach }\end{array}$ & {$[97,98]$} \\
\hline Janus & $\approx 120 \mathrm{~nm}$ & $\begin{array}{l}\text { Chemically different } \\
\text { domains } \\
\text { Anisotropic properties }\end{array}$ & $\begin{array}{l}\text { Targeted cancer, } \\
\text { simultaneous } \\
\text { differential release } \\
\text { of drugs }\end{array}$ & $\begin{array}{l}\text { Suitable for multiple functionalities } \\
\text { in one nanoplatform. }\end{array}$ & {$[90,91]$} \\
\hline
\end{tabular}




\subsection{Particle Synthesis of Iron-Gold Nanohybrids}

In the past decade, several synthetic methods for iron-gold NPs have been reported. Herein, we will discuss the thermal decomposition protocol, which is the most widely used approach to synthesize iron-gold NPs. Thermal decomposition has been further developed for the large-scale production of nanodimers, which is referred to as one-pot and two-pot synthesis methods. In two-pot synthesis, gold NPs are separately prepared and subsequently introduced into a mixture of 1-octadecane, oleic acid with oleylamine, which is used as the solvent. Iron salt is introduced at $150{ }^{\circ} \mathrm{C}$ and heated until $300{ }^{\circ} \mathrm{C}$. In one-pot synthesis, a gold precursor salt, $\mathrm{HAuCl}_{4}$ is introduced at $120^{\circ} \mathrm{C}$, affording $\mathrm{Cl}^{-}$ ions that control the dimensions of the iron-oxide moieties attached to the gold seed. Iron salt is added to this solution at $150{ }^{\circ} \mathrm{C}$, and temperature is subsequently raised to $300{ }^{\circ} \mathrm{C}$ to decompose $\mathrm{Fe}(\mathrm{CO})_{5}$, resulting in the formation of dimers with a narrow size distribution $[84,100]$. With the start of nucleation of $\mathrm{Fe}$, the free electrons from $\mathrm{Au}$ compensate for the charge induced by the polarized plane at the interface. As a result, Au NPs become deficient and unsuitable for multi-nucleation, resulting in a dumbbell-shaped structure. Once the synthesis of these dumbbell-shaped structures is completed, the nanoparticles are exposed to air, and $\mathrm{Fe}$ is oxidized to either $\mathrm{Fe}_{3} \mathrm{O}_{4}$ or $\gamma-\mathrm{Fe}_{2} \mathrm{O}_{3}$. NPs are dissolved in hexane in the presence of oleylamine for long-term stability as a dispersion [101].

In 2008, Yin et al. [102] have adjusted the Au-Fe molar ratios by following the same method to synthesize nanohybrids in size ranges of $2.5-3.5 \mathrm{~nm}$ and $15-16 \mathrm{~nm}$, followed by oxidization with CO. Wang et al. [103] have proposed slight modifications of this method by introducing absolute ethanol after heating the mixture at $300{ }^{\circ} \mathrm{C}$ for $20 \mathrm{~min}$.

Using Au seeds of 3 and $5 \mathrm{~nm}$-sized particles, Pablo et al. synthesized iron oxide-gold NPs with a dimer-like morphology owing to a single iron oxide nucleation event. This method is different than the multi-nucleation event, where the incorporation of a reducing agent or decreasing the reaction temperature leads to the formation of core-shell structures. However, increasing the size of Au seed to $8 \mathrm{~nm}$ yields to a flower-like structure [79].

In one method, silane-poly (ethylene glycol) and thiol-poly ( $\mathrm{N}$-isopropyl acrylamide) was used, which binds to the iron oxide and the gold surfaces, respectively. Gold nano-stars are grown by the injection of the dumbbell seeds in pre-reduced DMF solution of $\mathrm{HAuCL}_{4}$ at room temperature [14].

As a variation of the above method, after growing the $\mathrm{Fe}_{3} \mathrm{O}_{4}$ on $\mathrm{Au}$-seed particles, 1-octadecene is replaced by phenyl ether, which increases the reaction time from $45 \mathrm{~min}$ to $3 \mathrm{~h}$; the increase in the reaction time allows for complete crystallization. The NPs produced by this method exhibit strongly improved crystallinity and highly faceted growth mode based on an octahedral motif. In addition, the Janus NPs produced by this method are stable and non-toxic, and these NPs exhibit improved bulk-like magnetic properties [96].

As another variation, snowman-shaped gold-iron oxide nanohybrid dimers were obtained by the thermal decomposition of iron (III) oleate on pre-synthesized gold NPs. The gold NPs were synthesized in chloroform via reducing $\mathrm{HAuCl}_{4}$ with tert-butylamine borane in the presence of oleylamine. The size of the gold NPs was adjusted to a mean value of $6 \mathrm{~nm}$ by tuning the $\mathrm{HAuCl}_{4}$ /oleylamine ratio. The morphology of the $\mathrm{Au}-\mathrm{Fe}_{3} \mathrm{O}_{4}$ was found to be dependent on the iron (III) oleate concentration and size of the pre-synthesized AuNPs [104].

\subsection{Biomedical Applications of Iron-Gold Nanohybrids}

The combination of plasmonic and magnetic components has opened new venues for new applications. Selected examples of nanohybrids used in specific applications including drug delivery, hyperthermia, bioimaging, and biosensing are reviewed in the following section.

\subsubsection{Iron-Gold Nanohybrids as Delivery Carriers}

Nanohybrids combining magnetic and gold nanoparticles facilitate the selective release of drugs [105] which are successfully employed for gene [106] and drug delivery 
applications [23,107-110]. For instance, Reza et al. has reported a nanohybrid of iron oxide and gold NPs with a polymer such as PVA and cytotoxic drug such as docetaxel. In this study, a magnetic core is formed, which was coated by a silica layer, and docetaxel was subsequently encapsulated inside the PVA gel layer formed outside the silica-coated iron NPs. Finally, gold nanoparticles were attached under green light irradiation, leading to a functional anticancer multi-stimuli nanohybrid system. This nanohybrid system exhibited temperature-triggered drug release in vitro in cancerous and normal cells. Moreover, an increase amount of docetaxel was released in cancerous cells due to acidic $\mathrm{pH}$, indicating the efficiency of nanohybrid for selective delivery. Overall, the tumor inhibition was achieved by a combination of magnetically targeted delivery by iron NPs, $\mathrm{pH}$ and temperature-selective docetaxel release by PVA component, photothermal effect of gold NPs, and anti-tumor effects of docetaxel. This study reflects the successful report of irongold nanohybrids as a single system for multifunctional uses in cancer therapy [105]. In another example, Yun Quan-Li et al. have covalently attached a cytotoxic agent such as methotrexate to iron-gold alloy NPs and reported that with the increase in the applied magnetic field, the release of methotrexate increased in an incremental manner [111].

Singh et al. have reported the self-assembly of iron-gold core-shell nanoparticles with $\mathrm{N}$-Nitrosothioproline (NHTP), which is a nontoxic biological molecule that can release nitric oxide (NO), which is a cytotoxic agent on cleavage. The differential release of $\mathrm{NO}$ is observed from nanohybrids under different wavelengths of light, i.e., red, visible, white, and different time points, demonstrating the controlled-release effect of NO from nanohybrids. Furthermore, these nanohybrids are successfully employed for killing cancer cells (HeLa) in vitro [112].

Wi Shi et al. have developed iron-gold dumbbell NPs coated with polyethylenimine (PEI), a transfection agent, and then, they subsequently used these NPs as gene carriers to deliver green fluorescent protein in HEK 293T cells in vitro [106].

Lastly, dumbbell-like nanoparticles containing two different chemical surfaces, as well as being magnetically and optically activated, are particularly suitable for synchronized cell targeting and $\mathrm{pH}$-sensitive drug delivery [113]. Overall, these studies demonstrate that gold and iron based nanohybrids can be used for the controlled release of drugs and selective drug delivery.

\subsubsection{Iron-Gold Nanohybrids for Hyperthermia Applications}

Hyperthermia is an experimental cancer therapy, where the temperature is raised either locally or regionally in the range of $40-46{ }^{\circ} \mathrm{C}$ or for the whole body to destroy cancer cells and inhibit the growth of tumors $[114,115]$. Hyperthermia primarily aims to selectively kill malignant cells without causing any harm to normal cells [116]. There has been a great deal of research aiming to precisely position heat-delivery applicators such as catheters, microwave, and ultrasound applicators near or around the appropriate region, or administering nanoparticles and energy is focused on the tumor to raise its temperature [115].

Iron-gold NPs are the most extensively investigated NPs for hyperthermia-induced cancer therapy. Noninvasive alternating magnetic field (AMF) causes fluctuations in the magnetic moment of iron-oxide NPs, leading to the conversion of magnetic energy to thermal energy (magnetic hyperthermia) $[117,118]$. On the other hand, by the application of an infrared laser, AuNPs can convert light energy into heat energy, leading to the localized thermal ablation of tumor cells (photothermia) [15,119]. The size and shape of iron and gold nanoparticles play a crucial role on their properties. In fact, for enhancing the heat-generating capacity of magnetic nanoparticles, appropriate magnetization, control of size, fine tuning of shape, and anisotropy is essential [120]. For example, magnetic cubic NPs demonstrate superior heating capacities in comparison with those of spherical magnetic NPs [121]. Similarly, gold nano shells produce more heat compared to gold nanorods, even though both exhibit the same densities [122]. Furthermore, the addition of 
AuNPs has been reported to increase the magnetically induced heat generated by iron-oxide nanoparticles [123].

Espinosa et al. have fabricated a multifunctional nanohybrid composed up of a multiiron core and gold branched shell. Under the application of a magnetic field and laser irradiation, the resulting nanohybrids with varying gold branches exhibit a higher heat dissipation than that of either of them in vitro after dispersing in water. In vivo studies following intra-tumoral injection in mice showed that the iron oxide-gold nanohybrid caused a $20^{\circ} \mathrm{C}$ increase in the temperature within two minutes of the applied magnetic field and NIR exposure, and the heating performance lasts for three additional days, reflecting the advantage of incorporating dual hyperthermia modalities for cancer therapy [124]. In a similar approach, Janus nanoparticles comprising an iron oxide nanosphere and a gold nanostar exhibited a synergistic tumor ablation under the application of magnetic field and photothermal treatment compared to stand-alone procedures. Moreover, the magnetic-guided accumulation of Janus nanoparticles into tumors is observed after the intravenous administration of these multifunctional nanoparticles, leading to on-site delivery [125]. Photodynamic therapy (PDT) is another type of light-catalyzed process that uses a photosensitizer (PS), which is a molecule that generates high-energy cytotoxic reactive oxygen species to destroy cancer cells $[126,127]$. Nevertheless, the use of PSs is mainly hindered due to the presence of their main absorption band lying in the ultraviolet-visible (UV-vis) region, wherein light penetration into the tissue is shallow. In addition, PSs exhibit a lack of specificity toward tumors [128]. Hence, nanocarriers have been designed to improve their NIR absorption for enhanced light penetration and target specificity $[129,130]$. Methodologies that blend PDT with additional treatments have demonstrated synergistic effects in cancer therapy [131,132]. For instance, Saheel Bhana et al. developed a new type of nanohybrid comprising of an iron-oxide core and gold nano-popcorns with strong NIR absorption. This absorption has been achieved by coating the nano-popcorns with NIR-absorbing photosensitizer silicon, such as 2,3-naphthalocyannie dihydroxide and stabilization with PEG. This nanohybrid demonstrated superior photothermal and photodynamic properties with the aid of magnetic field-guided drug delivery in comparison with the combination treatment without using a magnetic field, and the two treatments alone indicating the significance of multifunctional composites based on iron and gold in hyperthermia [133]. However, hyperthermia is under study in clinical trials and is not widely available [134].

\subsubsection{Iron-Gold Nanohybrids for Bioimaging}

Multifunctional NPs have made possible theranostics for simultaneous imaging and therapy, as well as multi-modal imaging combining two or more imaging modalities. Dual surface-functionalized Janus nanocomposites of polystyrene $/ \mathrm{Fe}_{3} \mathrm{O}_{4} @ \mathrm{SiO}_{2}$ have been used for targeting tumor cells and simultaneously releasing drugs under an acidic intracellular environment [95]. Oxaliplatin- $\mathrm{Au}-\mathrm{Fe}_{3} \mathrm{O}_{4}$-herceptin is a promising multifunctional platform for the simultaneous magnetic traceable and human epithelial growth factor receptor 2 (HER2) targeted chemotherapy for gastric cancer. The nanocomposite has probes for mass spectroscopy and nuclear magnetic resonance imaging as well as a drug-release assay that releases oxaliplatin (a breast cancer drug) in an acidic medium. The $\mathrm{pH}$-controlled drug release lowers the dosage and period of administration for patients, thus reducing side effects and build-up of drug resistance in patients [135].

\subsubsection{Iron-Gold Nanohybrids as Biosensors}

Hybrid NPs have also been used in nanostructure-assisted laser desorption ionization mass spectrometry (nano-LDI). With advanced mass spectrometry instrumentation, NPs have been used as a matrix for ionization and analysis of biomolecules. This technique is known as matrix-assisted laser desorption/ionization mass spectrometry (MALDI-MS). The use of NPs in MS compared with the use of organic matrices makes sample preparation easier, with higher salt tolerance, absence of self-ionization, and more rapid data acquisition. 
NPs have been used in a dual "catch and detect" mode, serving as a capturing probe as well as an ionization matrix. Surface-functionalized with cationic legends, the AuNPs have been used to assess the cellular uptake of AuNPs in LDI-MS. This reported demonstrated that the AuNPs are quite stable in an intracellular environment to enable their use of a matrix. NPs can be used for targeting specific cells by conjugating them with aptamers. The cells can be targeted for rare protein capture, enrichment, drug delivery, and therapy [20].

\section{Toxicity Assessment}

With increasing studies and potential applications, it is imperative to assess the toxicity and biocompatibility of NPs. Due to their small sizes, NPs can cross cell membranes and perhaps the blood-brain barrier, thereby affecting intracellular structures and metabolisms. Gold NPs exhibit low toxicity due to their inert nature. However, the intake of iron nanoparticles leads to their accumulation in spleen, liver and lungs, and it was demonstrated that in some cases, they can cross the blood-brain barrier [136]. The toxicity of NPs is related to the production of ROS [137]. High ROS levels can disrupt DNA, alter protein structures and interactions, damage cells, modulate gene transcription, induce cell apoptosis and permeability, and change the cell morphology [138]. Specifically, these nanoparticles alter the blood coagulation systems, lead to cell lysis and inflammation, and reduce cell viability [139]. Gupta et al. have reported that the pullulan-coated iron NPs are nontoxic to human dermal fibroblasts comparing to the uncoated iron NPs [140]. Thus, the assessment of NPs is a major concern for the maintenance of the toxicity.

\subsection{In Vitro Toxicity Assessment Methods}

The in vitro assessment of NPs is feasible due to its cost-effective, rapid results, and ethical concerns. This type of toxicity assessment includes various assays, the details for which are explained below.

\subsubsection{Proliferation Assay}

A proliferation assay is employed to measure cell metabolism by examining metabolically active cells. The most common tetrazolium salt used for in vitro toxicity of NPs in this method is 3-(4,5-dimethyl-thiazol-2-yl)-2,5-diphenyltetrazolium bromide (MTT) [141]. This assay involves the assessment of tetrazolium salt. The resulting efficacy depends on the reaction conditions. Thymidine incorporation aids in the assessment of cell proliferation, but it is not feasible due to its toxic effects and high costs [142]. Another assay known as cologenic assay is also employed to examine cell proliferation by enabling the visual count of exposed NPs [143]. A study demonstrated that cell viability decreased by $85 \%$ in $72 \mathrm{~h}$ after exposure to $100 \mu \mathrm{m}$ nanoparticles [144]. In another study, Hu et al. reported that cytotoxicity was dose dependent when $\mathrm{Fe}_{3} \mathrm{O}_{4}$ nanoparticles were exposed on mouse macrophages for 1 and 4 days at $0.2 \mathrm{mg} / \mathrm{mL}$ [145].

\subsubsection{Apoptosis Assay}

Apoptosis is programmed cell death process that occurs in physiological and pathological conditions [146]. It is the major detection marker during in vitro toxicity assessment of NPs. Iron-gold NPs are toxic at high concentrations and can influence apoptosis, although the surface modifications can greatly reduce their toxicity. These NPs can be characterized using UV-Vis spectroscopy, dynamic light scattering, and field emission scanning electron microscope [147]. Cellular damage following NP treatment can be identified by various methods, including endotoxin and lactate dehydrogenase (LDH) signaling and oxidative stress detection supply; these valuable techniques expose the biomarkers that induce cellular damage [148]. Agarose gel electrophoresis can aid in differentiating cells that have undergone apoptotic and necrosis [149]. The attachment of hapten moieties to annexin $\mathrm{V}$ permits the labeling of the apoptotic cell. The annexin $\mathrm{V}$ assay monitors apoptotic events, while the caspase assays are beneficial for the identification of cellular apoptosis 
signals. Other assays including fluorogenic and chromogenic caspase, immunoblotting, and immunofluorescence caspase can also be used in the identification of apoptosis [148].

\subsubsection{Necrosis Assay}

Necrosis assessment enables the determination of cell viability by examining membrane integrity. When cells undergo necrosis following the uptake of iron-gold NPs, LDH is released into the surrounding extracellular environment, although its enzymatic activity is maintained [148]. The monitoring of the LDH enzymatic activity by using known concentrations of lactate and NAD via the use of enzymatic-linked immunosorbent assay (ELISA) or a UV-Vis spectrometer can indicate the rate of cell necrosis. During this process, membrane integrity can be examined using external dye binding with neutral red or trypan red [150]. These dyes cross the cell membrane and interact with lysosomes to induce surface changes, which in turn make the lysosomes fragile. Changes due to the NPs reduce the dye uptake and its binding, thereby permitting clear detection between viable and dead cells. Furthermore, cellular necrosis in cells can be identified by attaching hapten moieties to annexin $\mathrm{V}$, enabling apoptotic cell labeling and secondary stains that indicate necrosis [148].

\subsubsection{Oxidative Stress Assay}

Oxidation levels can be detected by the direct measurement of reactive oxygen species (ROS), when the structural alteration of NPs occurs, causing their uptake to lead to the ROS generation [151]. When clearance of these nanoparticles fails, it leads to oxidative stress, inflammation, and cell death. Moreover, uncleared NPs can further affect blood flow into organs, eventually leading to the rupture of blockages. Notably, the chemical composition and NP shapes greatly affect their interaction with the cells. Furthermore, ROS can be detected by using 2,2,6,6-tetramethylpiperidine (TEMP) following the electron paramagnetic resonance technique [152]. ROS can also be measured using fluorescent probes such as 5-(and -6)-carboxy-2,7-dichlorodihydrofluorescein diacetate (DCFDA) and dihydroethidium (DHE) [153]. Previously, gold NPs-induced DNA damage [154] and gold NPs causing autophagy with oxidative stress in human lung fibroblasts was shown [155].

\subsection{In Vivo Toxicity Assessment Methods}

This approach involves detection methods such as clearance, serum chemistry assessment, hematology, biodistribution, and histopathology. The clearance of NPs from body involves the estimation of excreted NPs at various periods after exposure [156]. Biodistribution measurements involve the examination of the NP localization routes in various tissues using radiolabels [157]. On the other hand, histopathology is employed to check the NP exposure in various tissues such as the eyes, lungs, liver, spleen, and kidneys [158]. In vivo studies have reported that the gold NPs induce apoptosis and acute inflammation in the liver [159]; however, similar studies involving other NPs are still lacking.

\section{Conclusions and Future Directions}

Hybrid nanoparticles have significant advantages in biomedicine because of their multifunctional capabilities. In particular, much progress has been made in the synthesis of iron-gold-based multifunctional hybrid NPs, and successful surface functionalization via different functional groups. Different structures of iron-gold-based hybrid nanoparticles have been evolved recently with unique properties corresponding to their structures.

Owing to their unique features, iron-gold hybrid nanoparticles have demonstrated to be ideal candidates as drug delivery vehicles in cancer therapy and several other biomedical applications. Their size and shape can be tuned by different synthetic methods and various surface modification approaches, making them suitable for a wide range of applications such as multimodal imaging, multimodal therapy, biosensing, and theranostics. Even though iron-gold NPs are becoming increasingly popular, considerable work still needs to 
be performed in terms of optimization of the synthetic routes to obtain better and robust nanohybrids for achieving enhanced targeted therapies.

Moreover, thus far, most studies based on iron-gold nanoparticle hybrids are still in a proof-of-concept stage, highlighting a need to establish detailed preclinical studies. Despite possessing unique physicochemical properties suitable for biomedical applications, inorganic nanoparticles suffer from significant toxicity issues. Hence, to enter clinical trials for humans, it is empirical to evaluate the pharmacokinetics and biodistribution of these nanohybrids first in preclinical studies. A careful estimation of toxicity parameters such as lethal dose, maximum tolerable dose, and side effects must be performed. In addition, it is crucial to determine the minimum number of modalities required in a nanoplatform to get the desired efficacy for the effective treatment of cancer economically. Determining these parameters will certainly prompt the transition of novel iron-gold-based hybrid nanoparticles from bench to bedside.

Author Contributions: Conceptualization, M.A.M.T. and V.K. (Veysel Kayser); writing—original draft preparation, M.A.M.T., V.K. (Varsha Komalla) and V.K. (Veysel Kayser); writing—review and editing, M.A.M.T., V.K. (Varsha Komalla) and V.K. (Veysel Kayser); supervision, V.K. (Veysel Kayser); All authors have read and agreed to the published version of the manuscript.

Funding: This research received no external funding.

Institutional Review Board Statement: Not applicable.

Informed Consent Statement: Not applicable.

Data Availability Statement: Not applicable.

Acknowledgments: The authors are grateful The Australian Centre for Microscopy \& Microanalysis (ACMM) technical staff at The University of Sydney for their help with TEM experiments. M.A.M.T. acknowledges the Saudi Arabian Culture Mission and the Ministry of health for HDR scholarship.

Conflicts of Interest: The authors declare no conflict of interest.

\section{Abbreviations}

$\begin{array}{ll}\mathrm{AFM} & \text { Atomic force microscopy } \\ \mathrm{Au} & \text { Gold } \\ \mathrm{Au}-\mathrm{Fe}_{3} \mathrm{O}_{4} & \text { Gold iron } \\ \text { DCFDA } & \text { 5-(and -6)-Carboxy-2,7-dichlorodihydrofluorescein diacetate } \\ \mathrm{DHE} & \text { Dihydroethidium } \\ \mathrm{DMF} & \text { Dimethylformamide } \\ \mathrm{DNA} & \text { Deoxyribonucleic acid } \\ \text { DOPA } & \text { Dihydroxy-L-phenylalanine } \\ \text { ELISA } & \text { Enzymatic-linked immunosorbent assay } \\ \text { EPR } & \text { Electron paramagnetic resonance } \\ \mathrm{Fe}(\mathrm{CO})_{5} & \text { Iron pentacarbonyl } \\ \mathrm{Fe} \mathrm{O}_{4} & \text { Iron magnetite } \\ \left(\gamma-\mathrm{Fe} \mathrm{O}_{3}\right) & \text { Maghemite } \\ \mathrm{HAuCl} & \text { Chloroauric acid } \\ \mathrm{HEK} 293 \mathrm{~T} & \text { Human embryonic kidney 293 cells } \\ \mathrm{HER} 2 & \text { Human epithelial growth factor receptor 2 } \\ \text { LDI-MS } & \text { Laser desorption and ionization mass spectrometry } \\ \text { LDH } & \text { Lactate dehydrogenase } \\ \mathrm{MRI} & \text { Magnetic resonance imaging } \\ \mathrm{MTT} & \text { 3-(4,5-Dimethyl-thiazol-2-yl)-2,5-diphenyltetrazolium bromide } \\ \mathrm{NAD} & \text { Nicotinamide-adenine dinucleotide } \\ \mathrm{NHTP} & \text { Nitrosothioproline } \\ \mathrm{NO} & \text { Nitric oxide } \\ & \end{array}$




$\begin{array}{ll}\text { NPs } & \text { Nanoparticles } \\ \text { NIR } & \text { Near-infrared } \\ \text { PDA } & \text { Polydopamine } \\ \text { PDT } & \text { Photodynamic therapy } \\ \text { PEG } & \text { Polyethylene glycol } \\ \text { PEI } & \text { Polyethylenimine } \\ \text { PVA } & \text { Polyvinyl alcohol } \\ \text { PVP } & \text { Poly vinyl pyrrolidone } \\ \text { ROS } & \text { Reactive oxygen species } \\ \text { SERS } & \text { Surface-enhanced Raman spectroscopy } \\ \text { SiO } & \text { Silica } \\ \text { SPIONs } & \text { Superparamagnetic iron oxide nanoparticle } \\ \text { SPR } & \text { Surface plasmon resonance } \\ \text { TEM } & \text { Transmission electron microscopy } \\ \text { TEMP } & \text { Tetramethylpiperidine } \\ \text { UV } & \text { Ultraviolet } \\ \text { VDW } & \text { Van der Waals }\end{array}$

\section{References}

1. Nikalje, A.P. Nanotechnology and its Applications in Medicine. Med. Chem. 2015, 5, 1-9. [CrossRef]

2. Huang, C.; Chen, X.; Xue, Z.; Wang, T. Effect of structure: A new insight into nanoparticle assemblies from inanimate to animate. Sci. Adv. 2020, 6, eaba1321. [CrossRef]

3. Rehan, F.; Ahemad, N.; Gupta, M. Casein nanomicelle as an emerging biomaterial: A comprehensive review. Colloids Surf. B Biointerfaces 2019, 179, 280-292. [CrossRef] [PubMed]

4. Jeevanandam, J.; Barhoum, A.; Chan, Y.S.; Dufresne, A.; Danquah, M.K. Review on Nanoparticles and Nanostructured Materials: History, Sources, Toxicity and Regulations. Beilstein J. Nanotechnol. 2018, 9, 1050-1074. [CrossRef]

5. Nho, R. Pathological effects of nano-sized particles on the respiratory system. Nanomed. Nanotechnol. Biol. Med. 2020, $29,102242$. [CrossRef]

6. $\quad$ Patra, J.K.; Das, G.; Fraceto, L.F.; Campos, E.V.R.; del Pilar Rodriguez-Torres, M.; Acosta-Torres, L.S.; Diaz-Torres, L.A.; Grillo, R.; Swamy, M.K.; Sharma, S.; et al. Nano based drug delivery systems: Recent developments and future prospects. J. Nanobiotechnol. 2018, 16, 71. [CrossRef]

7. Elbialy, N.S.; Fathy, M.M.; Khalil, W.M. Doxorubicin loaded magnetic gold nanoparticles for in vivo targeted drug delivery. Int. J. Pharm. 2015, 490, 190-199. [CrossRef] [PubMed]

8. Yhee, J.Y.; Son, S.; Son, S.; Joo, M.K.; Kwon, I.C. The EPR Effect in Cancer Therapy. In Cancer Targeted Drug Delivery; Springer: New York, NY, USA, 2013; pp. 621-632.

9. Nikolova, M.; Slavchov, R. Nanotechnology in Medicine. In Drug Discovery and Evaluation: Methods in Clinical Pharmacology; Springer International Publishing: Cham, Switzerland, 2020; pp. 533-546.

10. Fatima, H.; Kim, K.-S. Iron-based magnetic nanoparticles for magnetic resonance imaging. Adv. Powder Technol. 2018, 29, 2678-2685. [CrossRef]

11. Estelrich, J.; Escribano, E.; Queralt, J.; Busquets, M.A. Iron Oxide Nanoparticles for Magnetically-Guided and MagneticallyResponsive Drug Delivery. Int. J. Mol. Sci. 2015, 16, 8070-8101. [CrossRef]

12. Hedayatnasab, Z.; Dabbagh, A.; Abnisa, F.; Daud, W.M.A.W. Polycaprolactone-coated superparamagnetic iron oxide nanoparticles for in vitro magnetic hyperthermia therapy of cancer. Eur. Polym. J. 2020, 133, 109789. [CrossRef]

13. Kouassi, G.K.; Irudayaraj, J. Magnetic and Gold-Coated Magnetic Nanoparticles as a DNA Sensor. Anal. Chem. 2006, 78, 3234-3241. [CrossRef] [PubMed]

14. Reguera, J.; De Aberasturi, D.J.; Henriksen-Lacey, M.; Langer, J.; Espinosa, A.; Szczupak, B.; Wilhelm, C.; Liz-Marzán, L.M. Janus plasmonic-magnetic gold-iron oxide nanoparticles as contrast agents for multimodal imaging. Nanoscale 2017, 9, 9467-9480. [CrossRef]

15. Tian, Y.; Qiang, S.; Wang, L. Gold Nanomaterials for Imaging-Guided Near-Infrared in vivo Cancer Therapy. Front. Bioeng. Biotechnol. 2019, 7, 398. [CrossRef]

16. Cherukuri, P.; Glazer, E.S.; Curley, S.A. Targeted Hyperthermia Using Metal Nanoparticles. Adv. Drug Deliv. Rev. 2010, 62, 339-345. [CrossRef]

17. Ding, X.; Li, D.; Jiang, J. Gold-based Inorganic Nanohybrids for Nanomedicine Applications. Theranostics 2020, 10, 8061-8079. [CrossRef]

18. Larsen, G.K.; Farr, W.; Murph, S.E.H. Multifunctional Fe2O3-Au Nanoparticles with Different Shapes: Enhanced Catalysis, Photothermal Effects, and Magnetic Recyclability. J. Phys. Chem. C 2016, 120, 15162-15172. [CrossRef]

19. Das, P.; Fatehbasharzad, P.; Colombo, M.; Fiandra, L.; Prosperi, D. Multifunctional Magnetic Gold Nanomaterials for Cancer. Trends Biotechnol. 2019, 37, 995-1010. [CrossRef] [PubMed] 
20. Ocsoy, I.; Gulbakan, B.; Shukoor, M.I.; Xiong, X.; Chen, T.; Powell, D.H.; Tan, W. Aptamer-Conjugated Multifunctional Nanoflowers as a Platform for Targeting, Capture, and Detection in Laser Desorption Ionization Mass Spectrometry. ACS Nano 2013, 7, 417-427. [CrossRef]

21. Chinen, A.B.; Guan, C.M.; Ferrer, J.R.; Barnaby, S.N.; Merkel, T.J.; Mirkin, C.A. Nanoparticle Probes for the Detection of Cancer Biomarkers, Cells, and Tissues by Fluorescence. Chem. Rev. 2015, 115, 10530-10574. [CrossRef]

22. Ibarra, M.R.; Khlebtsov, G.N. Magnetic and Plasmonic Nanoparticles for Biomedical Devices. J. Appl. Phys. 2019, $126,170401$. [CrossRef]

23. Karamipour, S.; Sadjadi, M.; Farhadyar, N. Fabrication and spectroscopic studies of folic acid-conjugated Fe3O4@Au core-shell for targeted drug delivery application. Spectrochim. Acta Part A Mol. Biomol. Spectrosc. 2015, 148, 146-155. [CrossRef] [PubMed]

24. Nguyen, T.T.; Mammeri, F.; Ammar, S. Iron Oxide and Gold Based Magneto-Plasmonic Nanostructures for Medical Applications: A Review. Nanomaterials 2018, 8, 149. [CrossRef]

25. Guo, D.; Xie, G.; Luo, J. Mechanical properties of nanoparticles: Basics and applications. J. Phys. D Appl. Phys. $2014,47,013001$. [CrossRef]

26. Wang, X.B.; Liu, W.M. Nanoparticle-Based Lubricant Additives. In Encyclopedia of Tribology; Wang, Q.J., Chung, Y.W., Eds.; Springer: Boston, MA, USA, 2013; pp. 2369-2376.

27. Hussain, F.; Hojjati, M.; Okamoto, M.; Gorga, R. Polymer Matrix Nanocomposites, Processing, Manufacturing and Application: An Overview. J. Compos. Mater. 2006, 40, 1511-1575. [CrossRef]

28. Ramos, M.; Ortiz-Jordan, L.; Hurtado-Macias, A.; Flores, S.; Elizalde-Galindo, J.T.; Rocha, C.; Torres, B.; Zarei-Chaleshtori, M.; Chianelli, R.R. Hardness and Elastic Modulus on Six-Fold Symmetry Gold Nanoparticles. Materials 2013, 6, 198-205. [CrossRef]

29. Ilie, F. Models of nanoparticles movement, collision, and friction in chemical mechanical polishing (CMP). J. Nanopart. Res. 2012, 14 . [CrossRef]

30. Mougin, K.; Gnecco, E.; Rao, A.; Cuberes, T.; Jayaraman, S.; McFarland, E.W.; Haidara, H.; Meyer, E. Manipulation of Gold Nanoparticles: Influence of Surface Chemistry, Temperature, and Environment (Vacuum Versus Ambient Atmosphere). Langmuir 2008, 24, 1577-1581. [CrossRef] [PubMed]

31. Maharaj, D.; Bhushan, B. Effect of spherical Au nanoparticles on nanofriction and wear reduction in dry and liquid environments. Beilstein J. Nanotechnol. 2012, 3, 759-772. [CrossRef]

32. Sitti, M. Atomic Force Microcope Probe Based Controlled Pushing for Nanotribo-Logical Characterization. IEEE/ASME Trans. Mechatron. 2004, 9, 343-349. [CrossRef]

33. Hoshyar, N.; Gray, S.; Han, H.; Bao, G. The effect of nanoparticle size on in vivo pharmacokinetics and cellular interaction. Nanomedicine 2016, 11, 673-692. [CrossRef]

34. Buckley, A.; Hodgson, A.; Warren, J.; Guo, C.; Smith, R. Size-dependent deposition of inhaled nanoparticles in the rat respiratory tract using a new nose-only exposure system. Aerosol Sci. Technol. 2015, 50, 1-10. [CrossRef]

35. Lopez-Chaves, C.; Soto-Alvaredo, J.; Montes-Bayon, M.; Bettmer, J.; Llopis, J.; Sanchez-Gonzalez, C. Gold nanoparticles: Distribution, bioaccumulation and toxicity. In vitro and in vivo studies. Nanomed. Nanotechnol. Biol. Med. 2018, 14, 1-12. [CrossRef]

36. Yuan, H.; Li, J.; Bao, G.; Zhang, S. Variable Nanoparticle-Cell Adhesion Strength Regulates Cellular Uptake. Phys. Rev. Lett. 2010, 105, 138101. [CrossRef]

37. Lin, J.; Miao, L.; Zhong, G.; Lin, C.H.; Dargazangy, R.; Alexander-Katz, A. Understanding the synergistic effect of physicochemical properties of nanoparticles and their cellular entry pathways. Commun. Biol. 2020, 3, 1-10. [CrossRef] [PubMed]

38. Van Lehn, R.C.; Atukorale, P.U.; Carney, R.P.; Yang, Y.S.; Stellacci, F.; Irvine, D.J.; Alexander-Katz, A. Effect of Particle Diameter and Surface Composition on the Spontaneous Fusion of Monolayer-Protected Gold Nanoparticles with Lipid Bilayers. Nano Lett. 2013, 13, 4060-4067. [CrossRef] [PubMed]

39. Raliya, R.; Chadha, T.S.; Haddad, K.; Biswas, P. Perspective on Nanoparticle Technology for Biomedical Use. Curr. Pharm. Des. 2016, 22, 2481-2490. [CrossRef] [PubMed]

40. Wang, L.; Kafshgari, M.H.; Meunier, M. Optical Properties and Applications of Plasmonic-Metal Nanoparticles. Adv. Funct. Mater. 2020, 30, 2005400. [CrossRef]

41. Khlebtsov, N.G.; Dykman, L.A. Optical Properties and Biomedical Applications of Plasmonic Nanoparticles. J. Quant. Spectrosc. Radiat. Transf. 2010, 111, 1-35. [CrossRef]

42. Ovejero, J.G.; Morales, I.; De La Presa, P.; Mille, N.; Carrey, J.; Garcia, M.A.; Hernando, A.; Herrasti, P. Hybrid nanoparticles for magnetic and plasmonic hyperthermia. Phys. Chem. Chem. Phys. 2018, 20, 24065-24073. [CrossRef]

43. Lukianova-Hleb, E.; Hu, Y.; Latterini, L.; Tarpani, L.; Lee, S.; Drezek, R.A.; Hafner, J.H.; Lapotko, D.O. Plasmonic Nanobubbles as Transient Vapor Nanobubbles Generated around Plasmonic Nanoparticles. ACS Nano 2010, 4, 2109-2123. [CrossRef]

44. Karkan, S.F.; Mohammadhosseini, M.; Panahi, Y.; Milani, M.; Zarghami, N.; Akbarzadeh, A.; Abasi, E.; Hosseini, A.; Davaran, S. Magnetic nanoparticles in cancer diagnosis and treatment: A review. Artif. Cells Nanomed. Biotechnol. 2016, 45, 1-5. [CrossRef]

45. Akbulut, M. Nanoparticle-Based Lubrication Systems. J. Powder Met. Min. 2012, e101. [CrossRef]

46. Yu, P.; Yao, Y.; Wu, J.; Niu, X.; Rogach, A.L.; Wang, Z. Effects of Plasmonic Metal Core -Dielectric Shell Nanoparticles on the Broadband Light Absorption Enhancement in Thin Film Solar Cells. Sci. Rep. 2017, 7, 1-10. [CrossRef]

47. Dheyab, M.A.; Aziz, A.A.; Jameel, M.S.; Abu Noqta, O.; Mehrdel, B. Synthesis and coating methods of biocompatible iron oxide/gold nanoparticle and nanocomposite for biomedical applications. Chin. J. Phys. 2020, 64, 305-325. [CrossRef] 
48. Sahoo, B.; Devi, K.S.P.; Dutta, S.; Maiti, T.K.; Pramanik, P.; Dhara, D. Biocompatible Mesoporous Silica-Coated Superparamagnetic Manganese Ferrite Nanoparticles for Targeted Drug Delivery and Mr Imaging Applications. J. Colloid Interface Sci. 2014, 431, 31-41. [CrossRef]

49. Chen, F.; Hableel, G.; Zhao, E.R.; Jokerst, J.V. Multifunctional nanomedicine with silica: Role of silica in nanoparticles for theranostic, imaging, and drug monitoring. J. Colloid Interface Sci. 2018, 521, 261-279. [CrossRef]

50. Wu, W.; He, Q.; Chen, H.; Tang, J.; Nie, L. Sonochemical synthesis, structure and magnetic properties of air-stable Fe3O4/Au nanoparticles. Nanotechnology 2007, 18, 145609. [CrossRef]

51. Xu, Z.; Yanglong, H.; Shouheng, S. Magnetic Core/Shell Fe3o4/Au and Fe3o4/Au/Ag Nanoparticles with Tunable Plasmonic Properties. J. Am. Chem. Soc. 2007, 129, 8698-8699. [CrossRef] [PubMed]

52. Wang, W.; Luo, J.; Fan, Q.; Suzuki, M.; Suzuki, I.S.; Engelhard, M.H.; Lin, Y.; Kim, N.; Wang, J.Q.; Zhong, C.J. Monodispersed Core-Shell Fe3o4@Au Nanoparticles. J. Phys. Chem. B 2005, 109, 21593-21601. [CrossRef]

53. Baaziz, W.; Pichon, B.P.; Fleutot, S.; Liu, Y.; Lefevre, C.; Greneche, J.M.; Toumi, M.; Mhiri, T.; Begin-Colin, S. Magnetic Iron Oxide Nanoparticles: Reproducible Tuning of the Size and Nanosized-Dependent Composition, Defects, and Spin Canting. J. Phys. Chem. C 2014, 118, 3795-3810. [CrossRef]

54. Zhu, Y.; Da, H.; Yang, X.; Hu, Y. Preparation and characterization of core-shell monodispersed magnetic silica microspheres. Colloids Surf. A Physicochem. Eng. Asp. 2003, 231, 123-129. [CrossRef]

55. Peng, X.; Wang, Y.; Tang, X.; Liu, W. Functionalized magnetic core-shell $\mathrm{Fe}_{3} \mathrm{O}_{4} @ \mathrm{SiO}_{2}$ nanoparticles as selectivity-enhanced chemosensor for $\mathrm{Hg}(\mathrm{II})$. Dye. Pigment. 2011, 91, 26-32. [CrossRef]

56. Jin, A.; Wang, Y.; Lin, K.; Jiang, L. Nanoparticles Modified by Polydopamine: Working as “Drug” Carriers. Bioact. Mater. 2020, 5, 522-541. [CrossRef]

57. Zheng, W.; Fan, H.; Wang, L.; Jin, Z. Oxidative Self-Polymerization of Dopamine in an Acidic Environment. Langmuir 2015, 31, 11671-11677. [CrossRef] [PubMed]

58. Teodorescu, M.; Bercea, M. Poly(vinylpyrrolidone): A Versatile Polymer for Biomedical and Beyond Medical Applications. Polym. Technol. Eng. 2015, 54, 923-943. [CrossRef]

59. Lee, H.Y.; Lee, S.H.; Xu, C.; Xie, J.; Lee, J.H.; Wu, B.; Koh, A.L.; Wang, X.; Sinclair, R.; Wang, S.X.; et al. Synthesis and characterization of PVP-coated large core iron oxide nanoparticles as an MRI contrast agent. Nanotechnology 2008, $19,165101$. [CrossRef] [PubMed]

60. Zhang, Y.; Liu, J.Y.; Ma, S.; Zhang, Y.J.; Zhao, X.; Zhang, X.D.; Zhang, Z.D. Synthesis of PVP-coated ultra-small Fe3O4 nanoparticles as a MRI contrast agent. J. Mater. Sci. Mater. Electron. 2010, 21, 1205-1210. [CrossRef]

61. Huang, J.; Bu, L.; Xie, J.; Chen, K.; Cheng, Z.; Li, X.; Chen, X. Effects of Nanoparticle Size on Cellular Uptake and Liver MRI with Polyvinylpyrrolidone-Coated Iron Oxide Nanoparticles. ACS Nano 2010, 4, 7151-7160. [CrossRef] [PubMed]

62. Kas, H.S. Chitosan: Properties, preparations and application to microparticulate systems. J. Microencapsul. 1997, 14, 689-711. [CrossRef]

63. Kim, I.Y.; Seo, S.J.; Moon, H.S.; Yoo, M.K.; Park, I.Y.; Kim, B.C.; Cho, C.S. Chitosan and its derivatives for tissue engineering applications. Biotechnol. Adv. 2008, 26, 1-21. [CrossRef] [PubMed]

64. Qiao, T.; Wu, Y.; Jin, J.; Gao, W.; Xie, Q.; Wang, S.; Zhang, Y.; Deng, H. Conjugation of catecholamines on magnetic nanoparticles coated with sulfonated chitosan. Colloids Surf. A Physicochem. Eng. Asp. 2011, 380, 169-174. [CrossRef]

65. Kohler, N.; Fryxell, G.E.; Zhang, M. A Bifunctional Poly(ethylene glycol) Silane Immobilized on Metallic Oxide-Based Nanoparticles for Conjugation with Cell Targeting Agents. J. Am. Chem. Soc. 2004, 126, 7206-7211. [CrossRef] [PubMed]

66. Mengersen, F.; Bunjes, H. PEGylation of supercooled smectic cholesteryl myristate nanoparticles. Eur. J. Pharm. Biopharm. 2012, 81, 409-417. [CrossRef]

67. Illés, E.; Szekeres, M.; Tóth, I.Y.; Farkas, K.; Földesi, I.; Szabó, A.; Iván, B.; Tombácz, E. Pegylation of Superparamagnetic Iron Oxide Nanoparticles with Self-Organizing Polyacrylate-Peg Brushes for Contrast Enhancement in Mri Diagnosis. Nanomaterials 2018, 8, 776. [CrossRef]

68. Adoor, G.S.; Manjeshwar, L.D.; Naidu, B.V.K.; Sairam, M.; Aminabhavi, T. Poly(Vinyl Alcohol)/Poly(Methyl Methacrylate) Blend Membranes for Pervaporation Separation of Water+Isopropanol and Water+1,4-Dioxane Mixtures. J. Membr. Sci. 2006, 280, 594-602. [CrossRef]

69. Caramori, S.S.; Fernandes, K.F.; Junior, L.B.D.C. Immobilized Horseradish Peroxidase on Discs of Polyvinyl AlcoholGlutaraldehyde Coated with Polyaniline. Sci. World J. 2012, 2012, 1-8. [CrossRef] [PubMed]

70. Sanaeifar, N.; Rabiee, M.; Abdolrahim, M.; Tahriri, M.; Vashaee, D.; Tayebi, L. A novel electrochemical biosensor based on Fe 3 O 4 nanoparticles-polyvinyl alcohol composite for sensitive detection of glucose. Anal. Biochem. 2017, 519, 19-26. [CrossRef] [PubMed]

71. Li, J.; Hu, Y.; Yang, J.; Wei, P.; Sun, W.; Shen, M.; Zhang, G.; Shi, X. Hyaluronic acid-modified Fe3O4@Au core/shell nanostars for multimodal imaging and photothermal therapy of tumors. Biomaterials 2015, 38, 10-21. [CrossRef]

72. Gan, N.; Jin, H.; Li, T.; Zheng, L. Fe3o4/Au Magnetic Nanoparticle Amplifcation Strategies for Ultrasensitive Electrochemical Immunoassay of Alfa-Fetoprotein. Int. J. Nanomed. 2011, 6, 3259-3269. [CrossRef]

73. Chen, A.; Chatterjee, S. Nanomaterials based electrochemical sensors for biomedical applications. Chem. Soc. Rev. 2013, 42, 5425-5438. [CrossRef] 
74. Shams, S.F.; Ghazanfari, M.R.; Schmitz-Antoniak, C. Magnetic-Plasmonic Heterodimer Nanoparticles: Designing Contemporarily Features for Emerging Biomedical Diagnosis and Treatments. Nanomaterials 2019, 9, 97. [CrossRef] [PubMed]

75. Zhu, J.; Wu, J.; Liu, F.; Xing, R.; Zhang, C.; Yang, C.; Yin, H.; Hou, Y. Controlled synthesis of FePt-Au hybrid nanoparticles triggered by reaction atmosphere and FePt seeds. Nanoscale 2013, 5, 9141-9149. [CrossRef] [PubMed]

76. Ding, Q.; Liu, D.; Guo, D.; Yang, F.; Pang, X.; Che, R.; Zhou, N.; Xie, J.; Sun, J.; Huang, Z.; et al. Shape-controlled fabrication of magnetite silver hybrid nanoparticles with high performance magnetic hyperthermia. Biomaterials 2017, 124, 35-46. [CrossRef] [PubMed]

77. Rahaman, M.H.; Sarkar, T.; Kemp, B.A. Tunable and large plasmonic field enhancement in core-shell heterodimer/trimer. J. Electromagn. Waves Appl. 2019, 33, 2423-2433. [CrossRef]

78. Ahrberg, C.D.; Choi, J.W.; Chung, B.G. Automated droplet reactor for the synthesis of iron oxide/gold core-shell nanoparticles. Sci. Rep. 2020, 10, 1-9. [CrossRef]

79. Tancredi, P.; Da Costa, L.S.; Calderon, S.; Moscoso-Londoño, O.; Socolovsky, L.M.; Ferreira, P.J.; Muraca, D.; Zanchet, D.; Knobel, M. Exploring the synthesis conditions to control the morphology of gold-iron oxide heterostructures. Nano Res. 2019, 12, 1781-1788. [CrossRef]

80. Mahdavi, Z.; Rezvani, H.; Moraveji, M.K. Core-shell nanoparticles used in drug delivery-microfluidics: A review. RSC Adv. 2020, 10, 18280-18295. [CrossRef]

81. El-Toni, A.M.; Habila, M.A.; Labis, J.P.; Alothman, Z.A.; Alhoshan, M.; Elzatahry, A.A.; Zhang, F. Design, Synthesis and Applications of Core-Shell, Hollow Core, and Nanorattle Multifunctional Nanostructures. Nanoscale 2016, 8, 2510-2531. [CrossRef] [PubMed]

82. Lukosi, M.; Zhu, H.; Dai, S. Recent advances in gold-metal oxide core-shell nanoparticles: Synthesis, characterization, and their application for heterogeneous catalysis. Front. Chem. Sci. Eng. 2016, 10, 39-56. [CrossRef]

83. Woodard, L.E.; Dennis, C.L.; Borchers, J.A.; Attaluri, A.; Velarde, E.; Dawidczyk, C.; Searson, P.C.; Pomper, M.G.; Ivkov, R. Nanoparticle Architecture Preserves Magnetic Properties During Coating to Enable Robust Multi-Modal Functionality. Sci. Rep. 2018, 8, 12706. [CrossRef]

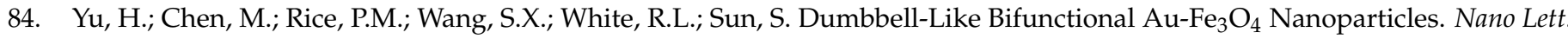
2005, 5, 379-382. [CrossRef] [PubMed]

85. Li, Y.; Zhang, Q.; Nurmikko, A.V.; Sun, S. Enhanced Magnetooptical Response in Dumbbell-like $\mathrm{Ag}_{-}-\mathrm{CoFe}_{2} \mathrm{O}_{4} \mathrm{Nanoparticle}$ Pairs. Nano Lett. 2005, 5, 1689-1692. [CrossRef]

86. Xu, C.; Xie, J.; Ho, D.; Wang, C.; Kohler, N.; Walsh, E.G.; Morgan, J.R.; Chin, Y.E.; Sun, S. Au-Fe ${ }_{3} \mathrm{O}_{4}$ Dumbbell Nanoparticles as Dual-Functional Probes. Angew. Chem. Int. Ed. 2007, 47, 173-176. [CrossRef]

87. Najafishirtari, S.; Guardia, P.; Scarpellini, A.; Prato, M.; Marras, S.; Manna, L.; Colombo, M. The effect of Au domain size on the $\mathrm{CO}$ oxidation catalytic activity of colloidal Au-FeOx dumbbell-like heterodimers. J. Catal. 2016, 338, 115-123. [CrossRef]

88. Landgraf, L.; Christner, C.; Storck, W.; Schick, I.; Krumbein, I.; Dähring, H.; Haedicke, K.; Heinz-Herrmann, K.; Teichgräber, U.; Reichenbach, J.R.; et al. A Plasma Protein Corona Enhances the Biocompatibility of Au@Fe3o4 Janus Particles. Biomaterials 2015, 68, 77-88. [CrossRef] [PubMed]

89. Jishkariani, D.; Wu, Y.; Wang, D.; Liu, Y.; van Blaaderen, A.; Murray, C.M. Preparation and Self-Assembly of Dendronized Janus $\mathrm{Fe}_{3} \mathrm{O}_{4}-\mathrm{Pt}$ and $\mathrm{Fe}_{3} \mathrm{O}_{4}-\mathrm{Au}$ Heterodimers. ACS Nano 2017, 11, 7958-7966. [CrossRef] [PubMed]

90. Zhang, L.; Zhang, M.; Zhou, L.; Han, Q.; Chen, X.; Li, S.; Li, L.; Su, Z.; Wang, C. Dual drug delivery and sequential release by amphiphilic Janus nanoparticles for liver cancer theranostics. Biomaterials 2018, 181, 113-125. [CrossRef] [PubMed]

91. Zhang, Q.; Zhang, L.; Li, S.; Chen, X.; Zhang, M.; Wang, T.; Li, L.; Wang, C. Designed Synthesis of $\mathrm{Au} / \mathrm{Fe}_{3} \mathrm{O}_{4} @ \mathrm{C}$ Janus Nanoparticles for Dual-Modal Imaging and Actively Targeted Chemo-Photothermal Synergistic Therapy of Cancer Cells. Chemistry 2017, 23, 17242-17248. [CrossRef] [PubMed]

92. Xie, J.; Zhang, F.; Aronova, M.; Zhu, L.; Lin, X.; Quan, Q.; Liu, G.; Zhang, G.; Choi, K.Y.; Kim, K.; et al. Manipulating the Power of an Additional Phase: A Flower-like $\mathrm{Au}-\mathrm{Fe}_{3} \mathrm{O}_{4}$ Optical Nanosensor for Imaging Protease Expressions In vivo. ACS Nano 2011, 5, 3043-3051. [CrossRef] [PubMed]

93. Quaresma, P.; Osório, I.; Dória, G.; Carvalho, P.A.; Pereira, A.; Langer, J.; Araújo, P.; Pastoriza-Santos, I.; Liz-Marzán, L.M.; Franco, R.; et al. Star-Shaped Magnetite@Gold Nanoparticles for Protein Magnetic Separation and Sers Detection. RSC Adv. 2014, 4, 3659-3667. [CrossRef]

94. Nguyen, T.T.; Lau-Truong, S.; Mammeri, F.; Ammar, S. Star-Shaped Fe3-xO4-Au Core-Shell Nanoparticles: From Synthesis to SERS Application. Nanomaterials 2020, 10, 294. [CrossRef]

95. Efremova, M.V.; Naumenko, V.A.; Spasova, M.; Garanina, A.S.; Abakumov, M.A.; Blokhina, A.D.; Melnikov, P.A.; Prelovskaya, A.O.; Heidelmann, M.; Li, Z.A.; et al. Magnetite-Gold nanohybrids as ideal all-in-one platforms for theranostics. Sci. Rep. 2018, 8, 1-19. [CrossRef]

96. Kozenkova, E.; Levada, K.; Efremova, M.V.; Omelyanchik, A.; Nalench, Y.A.; Garanina, A.S.; Pshenichnikov, S.; Zhukov, D.G.; Lunov, O.; Lunova, M.; et al. Multifunctional Fe3o4-Au Nanoparticles for the Mri Diagnosis and Potential Treatment of Liver Cancer. Nanomaterials 2020, 10, 1646. [CrossRef]

97. Gole, A.; Stone, J.W.; Gemmill, W.R.; zur Loye, H.C.; Murphy, C.J. Iron Oxide Coated Gold Nanorods: Synthesis, Characterization, and Magnetic Manipulation. Langmuir 2008, 24, 6232-6237. [CrossRef] 
98. Chapman, B.S.; Wu, W.C.; Li, Q.; Holten-Andersen, N.; Tracy, J.B. Heteroaggregation Approach for Depositing Magnetite Nanoparticles onto Silica-Overcoated Gold Nanorods. Chem. Mater. 2017, 29, 10362-10368. [CrossRef]

99. Kwizera, E.A.; Chaffin, E.; Shen, X.; Chen, J.; Zou, Q.; Wu, Z.; Gai, Z.; Bhana, S.; O'Connor, R.; Wang, L.; et al. Size- and ShapeControlled Synthesis and Properties of Magnetic-Plasmonic Core-Shell Nanoparticles. J. Phys. Chem. C 2016, 120, 10530-10546. [CrossRef]

100. Guardia, P.; Riedinger, A.; Nitti, S.; Pugliese, G.; Marras, S.; Genovese, A.; Materia, M.E.; Lefevre, C.; Manna, L.; Pellegrino, T. One pot synthesis of monodisperse water soluble iron oxide nanocrystals with high values of the specific absorption rate. J. Mater. Chem. B 2014, 2, 4426-4434. [CrossRef] [PubMed]

101. Javed, Y.; Hussain, M.I.; Yaseen, M.; Asif, M. Gold-Iron Oxide Nanohybrids: Characterization and Biomedical Applications; Taylor \& Francis: Milton, UK, 2019.

102. Yin, H.; Wang, C.; Zhu, H.; Overbury, S.H.; Sun, S.; Dai, S. Colloidal deposition synthesis of supported gold nanocatalysts based on $\mathrm{Au}-\mathrm{Fe} 3 \mathrm{O} 4$ dumbbell nanoparticles. Chem. Commun. 2008, 4357-4359. [CrossRef] [PubMed]

103. Wang, C.; Yin, H.; Dai, S.; Sun, S. A General Approach to Noble Metal-Metal Oxide Dumbbell Nanoparticles and Their Catalytic Application for CO Oxidation. Chem. Mater. 2010, 22, 3277-3282. [CrossRef]

104. Zhao, J.; Tu, K.; Liu, Y.; Qin, Y.; Wang, X.; Qi, L.; Shi, D. Photo-controlled aptamers delivery by dual surface gold-magnetic nanoparticles for targeted cancer therapy. Mater. Sci. Eng. C 2017, 80, 88-92. [CrossRef] [PubMed]

105. Taheri-Ledari, R.; Zhang, W.; Radmanesh, M.; Mirmohammadi, S.S.; Maleki, A.; Cathcart, N.; Kitaev, V. Multi-Stimuli Nanocomposite Therapeutic: Docetaxel Targeted Delivery and Synergies in Treatment of Human Breast Cancer Tumor. Small 2020, 16, 2002733. [CrossRef] [PubMed]

106. Shi, W.; Liu, X.; Wei, C.; Xu, Z.J.; Sim, S.S.W.; Liu, L.; Xu, C. Micro-optical coherence tomography tracking of magnetic gene transfection via $\mathrm{Au}-\mathrm{Fe} 3 \mathrm{O} 4 \mathrm{dumbbell} \mathrm{nanoparticles.} \mathrm{Nanoscale} \mathrm{2015,} \mathrm{7,} \mathrm{17249-17253.} \mathrm{[CrossRef]}$

107. Sood, A.; Varun, A.; Shah, J.; Kotnala, R.K.; Jain, T.K. Multifunctional Gold Coated Iron Oxide Core-Shell Nanoparticles Stabilized Using Thiolated Sodium Alginate for Biomedical Applications. Mater. Sci. Eng. C 2017, 80, 274-281. [CrossRef]

108. Ravichandran, M.; Velumani, S.; Ramirez, J.T.; Vera, A.; Leija, L. Biofunctionalized Mnfe2o4@Au Core-Shell Nanoparticles for Ph-Responsive Drug Delivery and Hyperthermal Agent for Cancer Therapy. Artif. Cells Nanomed. Biotechnol. 2018, 46, S993-S1003.

109. Wagstaff, A.J.; Brown, S.D.; Holden, M.R.; Craig, G.E.; Plumb, J.A.; Brown, R.E.; Schreiter, N.; Chrzanowski, W.; Wheate, N.J Cisplatin Drug Delivery Using Gold-Coated Iron Oxide Nanoparticles for Enhanced Tumour Targeting with External Magnetic Fields. Inorg. Chim. Acta 2012, 393, 328-333. [CrossRef]

110. Arora, V.; Sood, A.; Kumari, S.; Kumaran, S.S.; Jain, T.K. Hydrophobically modified sodium alginate conjugated plasmonic magnetic nanocomposites for drug delivery \& magnetic resonance imaging. Mater. Today Commun. 2020, 25, 101470. [CrossRef]

111. Li, Y.Q.; Xu, M.; Dhawan, U.; Liu, W.C.; Wu, K.T.; Liu, X.R.; Lin, C.; Zhao, G.; Wu, Y.C.; Chung, R.J. Iron-gold alloy nanoparticles serve as a cornerstone in hyperthermia-mediated controlled drug release for cancer therapy. Int. J. Nanomed. 2018, 13, 5499-5509. [CrossRef]

112. Singh, N.; Patel, K.; Sahoo, S.K.; Kumar, R. Human nitric oxide biomarker as potential NO donor in conjunction with superparamagnetic iron oxide @ gold core shell nanoparticles for cancer therapeutics. Colloids Surf. B Biointerfaces 2018, 163, 246-256. [CrossRef]

113. Xu, C.; Wang, B.; Sun, S. Dumbbell-like Au-Fe3O4 Nanoparticles for Target-Specific Platin Delivery. J. Am. Chem. Soc. 2009, 131, 4216-4217. [CrossRef] [PubMed]

114. Vilas-Boas, V.; Carvalho, F.; Espiña, B. Magnetic Hyperthermia for Cancer Treatment: Main Parameters Affecting the Outcome of In Vitro and In Vivo Studies. Molecules 2020, 25, 2874. [CrossRef] [PubMed]

115. Hegyi, G.; Szigeti, G.P.; Szász, A. Hyperthermia versus Oncothermia: Cellular Effects in Complementary Cancer Therapy. Evid. Based Complement. Altern. Med. 2013, 2013, 1-12. [CrossRef]

116. Berry, C.C.; Curtis, A.S.G. Functionalisation of Magnetic Nanoparticles for Applications in Biomedicine. J. Phys. D Appl. Phys. 2003, 36, R198-R206. [CrossRef]

117. Moise, S.; Byrne, J.M.; El Haj, A.J.; Telling, N.D. The Potential of Magnetic Hyperthermia for Triggering the Differentiation of Cancer Cells. Nanoscale 2018, 10, 20519-20525. [CrossRef]

118. Albarqi, H.A.; Demessie, A.A.; Sabei, F.Y.; Moses, A.S.; Hansen, M.N.; Dhagat, P.; Taratula, O.R.; Taratula, O. Systemically Delivered Magnetic Hyperthermia for Prostate Cancer Treatment. Pharmaceutics 2020, 12, 1020. [CrossRef] [PubMed]

119. Nam, J.; Son, S.; Ochyl, L.J.; Kuai, R.; Schwendeman, A.; Moon, J.J. Chemo-photothermal therapy combination elicits anti-tumor immunity against advanced metastatic cancer. Nat. Commun. 2018, 9, 1-13. [CrossRef]

120. Dennis, C.; Ivkov, R. Physics of Heat Generation Using Magnetic Nanoparticles for Hyperthermia. Int. J. Hyperth. 2013, 29, 715-729. [CrossRef]

121. Martínez, F.P.; Simeonidis, K.; Makridis, A.; Angelakeris, M.; Iglesias, O.; Guardia, P.; Cabot, A.; Yedra, L.; Estradé, S.; Peiró, F.; et al. Learning from Nature to Improve the Heat Generation of Iron-Oxide Nanoparticles for Magnetic Hyperthermia Applications. Sci. Rep. 2013, 3, 1652. [CrossRef] [PubMed]

122. Pattani, V.P.; Tunnell, J.W. Nanoparticle-Mediated Photothermal Therapy: A Comparative Study of Heating for Different Particle Types. Lasers Surg. Med. 2012, 44, 675-684. [CrossRef] [PubMed] 
123. Bell, G.; Bogart, L.K.; Southern, P.; Olivo, M.; Pankhurst, Q.A.; Parkin, I.P. Enhancing the Magnetic Heating Capacity of Iron Oxide Nanoparticles through Their Postproduction Incorporation into Iron Oxide-Gold Nanocomposites. Eur. J. Inorg. Chem. 2017, 18, 2386-2395. [CrossRef]

124. Espinosa, A.; Bugnet, M.; Radtke, G.; Neveu, S.; Botton, G.A.; Wilhelm, C.; Abou-Hassan, A. Can magneto-plasmonic nanohybrids efficiently combine photothermia with magnetic hyperthermia? Nanoscale 2015, 7, 18872-18877. [CrossRef]

125. Espinosa, A.; Reguera, J.; Curcio, A.; Muñoz-Noval, Á.; Kuttner, C.; Van De Walle, A.; Liz-Marzán, L.M.; Wilhelm, C. Janus Magnetic-Plasmonic Nanoparticles for Magnetically Guided and Thermally Activated Cancer Therapy. Small 2020, 16, e1904960. [CrossRef]

126. Kessel, D. Photodynamic therapy: Apoptosis, paraptosis and beyond. Apoptosis 2020, 25, 611-615. [CrossRef]

127. Lan, M.; Zhao, S.; Liu, W.; Lee, C.; Zhang, W.; Wang, P. Photosensitizers for Photodynamic Therapy. Adv. Health Mater. 2019, 8, e1900132. [CrossRef] [PubMed]

128. Park, W.; Cho, S.; Han, J.; Shin, H.; Na, K.; Lee, B.; Kim, D.H. Advanced smart-photosensitizers for more effective cancer treatment. Biomater. Sci. 2018, 6, 79-90. [CrossRef]

129. Kim, H.S.; Lee, D.Y. Near-Infrared-Responsive Cancer Photothermal and Photodynamic Therapy Using Gold Nanoparticles. Polymers 2018, 10, 961. [CrossRef] [PubMed]

130. Loh, X.J.; Dou, Q.Q.; Ye, E.; Teng, C.P. Effective near-infrared photodynamic therapy assisted by upconversion nanoparticles conjugated with photosensitizers. Int. J. Nanomed. 2015, 10, 419-432. [CrossRef] [PubMed]

131. Chen, Y.; Gao, Y.; Li, Y.; Wang, K.; Zhu, J. Synergistic chemo-photodynamic therapy mediated by light-activated ROS-degradable nanocarriers. J. Mater. Chem. B 2019, 7, 460-468. [CrossRef] [PubMed]

132. Song, Y.; Wang, L.; Xie, Z. Metal-Organic Frameworks for Photodynamic Therapy: Emerging Synergistic Cancer Therapy. Biotechnol. J. 2021, 16, e1900382. [CrossRef]

133. Bhana, S.; Lin, G.; Wang, L.; Starring, H.; Mishra, S.R.; Liu, G.; Huang, X. Near-Infrared-Absorbing Gold Nanopopcorns with Iron Oxide Cluster Core for Magnetically Amplified Photothermal and Photodynamic Cancer Therapy. ACS Appl. Mater. Interfaces 2015, 7, 11637-11647. [CrossRef]

134. National Cancer Institute. Hyperthermia in Cancer Treatment. Available online: https://www.cancer.gov/about-cancer/ treatment/types/surgery/hyperthermia-fact-sheet (accessed on 14 March 2021).

135. Liu, D.; Li, X.; Chen, C.; Li, C.; Zhou, C.; Zhang, W.; Zhao, J.; Fan, J.; Cheng, K.; Chen, L. Target-Specific Delivery of Oxaliplatin to Her2-Positive Gastric Cancer Cells in Vivo Using Oxaliplatin-Au-Fe3o4-Herceptin Nanoparticles. Oncol. Lett. 2018, 15, 8079-8087. [CrossRef]

136. Liu, G.; Gao, J.; Ai, H.; Chen, X. Applications and Potential Toxicity of Magnetic Iron Oxide Nanoparticles. Small 2013, 9 , 1533-1545. [CrossRef]

137. Sharifi, S.; Behzadi, S.; Laurent, S.; Forrest, M.L.; Stroeve, P.; Mahmoudi, M. Toxicity of nanomaterials. Chem. Soc. Rev. 2011, 41, 2323-2343. [CrossRef] [PubMed]

138. Soenen, S.; De Cuyper, M. Assessing Iron Oxide Nanoparticle Toxicity in Vitro: Current Status and Future Prospects. Nanomedicine 2010, 5, 1261-1275. [CrossRef]

139. Naqvi, S.; Samim, M.; Abdin, M.Z.; Ahmad, F.J.; Maitra, A.N.; Prashant, C.K.; Dinda, A. Concentration-Dependent Toxicity of Iron Oxide Nanoparticles Mediated by Increased Oxidative Stress. Int. J. Nanomed. 2010, 5, 983-989. [CrossRef]

140. Gupta, A.K.; Guptab, M. Cytotoxicity suppression and cellular uptake enhancement of surface modified magnetic nanoparticles. Biomaterials 2005, 26, 1565-1573. [CrossRef]

141. Sayes, C.M.; Reed, K.L.; Warheit, D.B. Assessing Toxicity of Fine and Nanoparticles: Comparing In Vitro Measurements to In Vivo Pulmonary Toxicity Profiles. Toxicol. Sci. 2007, 97, 163-180. [CrossRef]

142. Saber, H.; Frazier, J. Cellular Toxicity of Hydrazine in Primary Rat Hepatocytes. Toxicol. Sci. 2002, 69, 424-432.

143. Casey, A.; Herzog, E.; Davoren, M.; Lyng, F.; Byrne, H.; Chambers, G. Spectroscopic Analysis Confirms the Interaction between Swcnt and Various Dyes Commonly Used to Assess Cytotoxicity. Carbon 2007, 45, 1425-1432. [CrossRef]

144. Tian, F.; Cui, D.; Schwarz, H.; Estrada, G.G.; Kobayashi, H. Cytotoxicity of single-wall carbon nanotubes on human fibroblasts. Toxicol. Vitr. 2006, 20, 1202-1212. [CrossRef]

145. Hu, K.G.N.; Cen, L.; Kang, E.T. Cellular Response to Magnetic Nanoparticles "PEGylated" via Surface-Initiated Atom Transfer Radical Polymerization. Biomacromolecules 2006, 7, 809-816. [CrossRef]

146. Elmore, S. Apoptosis: A review of programmed cell death. Toxicol. Pathol. 2007, 35, 495-516. [CrossRef] [PubMed]

147. Chakraborty, A.; Das, A.; Raha, S.; Barui, A. Size-dependent apoptotic activity of gold nanoparticles on osteosarcoma cells correlated with SERS signal. J. Photochem. Photobiol. B Biol. 2020, 203, 111778. [CrossRef]

148. Savage, D.T.; Zach, J.H.; Dziubla, T.D. In Vitro Methods for Assessing Nanoparticle Toxicity. In Nanotoxicity: Methods and Protocols; Zhang, Q., Ed.; Springer: New York, NY, USA, 2019; pp. 1-29.

149. Suman, S.; Pandey, A.; Chandna, S. An improved non-enzymatic "DNA ladder assay" for more sensitive and early detection of apoptosis. Cytotechnology 2011, 64, 9-14. [CrossRef]

150. Hu, W.; Culloty, S.; Darmody, G.; Lynch, S.; Davenport, J.; Ramirez-Garcia, S.; Dawson, K.; Lynch, I.; Doyle, H.; Sheehan, D. Neutral red retention time assay in determination of toxicity of nanoparticles. Mar. Environ. Res. 2015, 111, 158-161. [CrossRef]

151. Dayem, A.A.; Hossain, M.K.; Bin Lee, S.; Kim, K.; Saha, S.K.; Yang, G.-M.; Choi, H.Y.; Cho, S.-G. The Role of Reactive Oxygen Species (ROS) in the Biological Activities of Metallic Nanoparticles. Int. J. Mol. Sci. 2017, 18, 120. [CrossRef] 
152. Kumar, V.; Sharma, N.; Maitra, S.S. In vitro and in vivo toxicity assessment of nanoparticles. Int. Nano Lett. 2017, 7, $243-256$. [CrossRef]

153. Katerji, M.; Filippova, M.; Duerksen-Hughes, P. Approaches and Methods to Measure Oxidative Stress in Clinical Samples: Research Applications in the Cancer Field. Oxidative Med. Cell. Longev. 2019, 2019, 1-29. [CrossRef]

154. Li, J.J.; Zou, L.; Hartono, D.; Ong, C.N.; Bay, B.H.; Yung, L.Y.L. Gold Nanoparticles Induce Oxidative Damage in Lung Fibroblasts in Vitro. Adv. Mater. 2008, 20, 138-142. [CrossRef]

155. Li, J.J.; Hartono, D.; Ong, C.N.; Bay, B.H.; Yung, L.Y.L. Autophagy and Oxidative Stress Associated with Gold Nanoparticles. Biomaterials 2010, 31, 5996-6003. [CrossRef] [PubMed]

156. Li, P.; Wei, Z.; Wu, T.; Peng, Q.; Li, Y. Au-ZnO Hybrid Nanopyramids and Their Photocatalytic Properties. J. Am. Chem. Soc. 2011, 133, 5660-5663. [CrossRef]

157. Kim, S.C.; Kim, D.W.; Shim, Y.H.; Bang, J.S.; Oh, H.S.; Seo, M.H. In vivo evaluation of polymeric micellar paclitaxel formulation: Toxicity and efficacy. J. Control. Release 2001, 72, 191-202. [CrossRef] [PubMed]

158. Zhu, M.T.; Feng, W.Y.; Wang, B.; Wang, T.C.; Gu, Y.Q.; Wang, M.; Wang, Y.; Ouyang, H.; Zhao, Y.L.; Chai, Z.F. Comparative study of pulmonary responses to nano-and submicron-sized ferric oxide in rats. Toxicology 2008, 247, 102-111. [CrossRef]

159. Cho, W.S.; Cho, M.; Jeong, J.; Choi, M.; Cho, H.Y.; Han, B.S.; Kim, S.H.; Kim, H.O.; Lim, Y.T.; Chung, B.H.; et al. Acute toxicity and pharmacokinetics of 13 nm-sized PEG-coated gold nanoparticles. Toxicol. Appl. Pharmacol. 2009, 236, 16-24. [CrossRef] [PubMed] 